This is the Accepted Author Manuscript of the following publication:

\title{
Positron emission tomography in amyotrophic lateral sclerosis: Towards targeting of molecular pathological hallmarks
}

Willekens SM, Van Weehaeghe D, Van Damme P, Van Laere K.

Published by Springer

in European Journal of Nuclear Medicine and Molecular Imaging

March 2017, Volume 44, Issue 3, pp 533-547

First published online: 8 December 2016

DOI: $10.1007 / \mathrm{s} 00259-016-3587-y$

The final publication is available at:

http://link.springer.com/article/10.1007\%2Fs00259-016-3587-y 


\section{Positron Emission Tomography in Amyotrophic Lateral Sclerosis: Towards Targeting of Molecular Pathological Hallmarks}

Stefanie M.A. Willekens ${ }^{1}$, Donatienne Van Weehaeghe ${ }^{1}$, Philip Van Damme ${ }^{2,3,4,5}$, Koen Van Laere $^{1,4}$

${ }^{1}$ Division of Nuclear Medicine, Department of Imaging and Pathology, University Hospitals Leuven and KU Leuven, Belgium

${ }^{2}$ Department of Neurology, University Hospitals Leuven, Belgium

${ }^{3} \mathrm{KU}$ Leuven, Department of Neurosciences, Experimental Neurology

${ }^{4}$ Leuven Research Institute for Neuroscience and Disease (LIND), Leuven Belgium

${ }^{5}$ VIB, Vesalius Research Center, Laboratory of Neurobiology, Leuven, Belgium

Corresponding author: Stefanie Willekens

Address: UZ Gasthuisberg, Nucleaire Geneeskunde

Herestraat 49

BE-3000 Leuven

Belgium

Email: Stefanie.willekens@uzleuven.be

Phone/Fax: +3216349103 / +3216

Running head: PET in ALS

Word count: 5993 


\begin{abstract}
The past decades, extensive efforts have been made to expand knowledge on Amyotrophic Lateral Sclerosis (ALS). However, clinical translation of this research in terms of earlier diagnosis and improved therapy, remains challenging. Since more than $30 \%$ of motor neurons are lost when symptoms become clinically apparent, techniques allowing non-invasive, in vivo detection of motor neuron degeneration are needed in the early, pre-symptomatic disease stage. Furthermore, it has become apparent that non-motor signs play an important role in the disease and there is an overlap with cognitive disorders, such as frontotemporal dementia (FTD). Radionuclide imaging, such as positron emission tomography (PET) and single photon emission computed tomography (SPECT), form an attractive approach to quantitatively monitor the ongoing neurodegenerative processes. Although $\left[{ }^{18} \mathrm{~F}\right]-\mathrm{FDG}$ has been recently proposed as a potential biomarker for ALS, active targeting of the underlying pathologic molecular processes is likely to unravel further valuable disease information and may help to decipher the pathogenesis of ALS. In this review we provide an overview of radiotracers that have already been applied in ALS and discuss possible novel targets for in vivo imaging of various pathogenic processes underlying ALS onset and progression.
\end{abstract}

Key words: ALS, neurodegeneration, PET, targets, radiotracers 


\section{Introduction}

Amyotrophic lateral sclerosis (ALS), also known as Lou Gehrig's or Charcot's disease, is a devastating and fatal adult-onset neurodegenerative disorder characterized by progressive degeneration of both upper motor neurons (UMN) in the motor cortex and lower motor neurons (LMN) in the spinal cord and brainstem. This ensuing motor neuron loss results in fasciculation's, muscle wasting, weakness, spasticity and paralysis. Eventually, respiratory muscle weakness results in fatal respiratory failure in most ALS patients. ALS is part of a motor neuron disease spectrum also containing primary lateral sclerosis (PLS), showing exclusively UMN involvement, and progressive muscular atrophy (PMA), showing exclusively LMN involvement; both may progress to ALS in later disease stages [1-3].

Although ALS was already discovered as disease entity over 150 years ago, many questions regarding the cause, onset, non-motor impact and progression of the disease remain unanswered [4]. The median survival of ALS patients still does not exceed 36 months and the absence of a suitable diseasemodifying approach or neuroprotective drug, is an important hurdle in ALS management [5]. Despite the large number of clinical trials testing varieties of possible therapeutic agents, Riluzole (2-amino-6(trifluoromethoxy) benzothiazole) remains the only FDA approved drug for ALS. Riluzole is an antiglutamatergic drug that suppresses glutamate release, prevents glutamate receptor hypofunction and stimulates glutamate uptake by activation of glutamate transporters [6-8]. Unfortunately, this glutamate-modulating agent increases overall survival with only 3 to 4 months $[9,10]$. Given the multisystem involvement in ALS pathogenesis, the interest in drug cocktails, acting on a combination of disease-regulating targets, is rising [11].

Of all ALS cases, only 5-10\% is familial (fALS), mostly showing dominant Mendelian inheritance patterns [12], while the majority are sporadic cases (sALS). Several gene mutations, such as mutations in superoxide dismutase 1 (SOD1) located on chromosome 21 and responsible for $20 \%$ of fALS cases [13], fused in sarcoma (FUS) located on chromosome 16 and responsible for 3-5\% of fALS cases) [14, 15], and TAR-DNA binding protein (TDP-43) located on chromosome 1 and responsible for $5 \%$ of $\mathrm{fALS}$ cases [16]; were identified as causative for ALS. However, the gene defect currently recognized as the major genetic cause of ALS ( $40 \%$ of fALS cases) is a hexanucleotide repeat expansion in the chromosome 9 open reading frame 72 gene (C9orf72). Patients harboring this repeat usually present younger, show poorer survival and typically have a strong family history of neurodegenerative disease [17-19]. Several of these fALS causing gene mutations can also cause frontotemporal dementia (FTD). Furthermore, it has been shown that the majority of ALS cases and a subset of FTD cases share pathophysiological characteristics with aggregation of TDP-43 [20-22], and about 15\% of all ALS patients have clinically 
apparent cognitive impairment $[23,24]$, suggesting that both disorders form a clinical continuum. Recently, Canosa et al. showed significant differences in frontal and prefrontal glucose metabolism in patients with stand-alone ALS when compared to patients with co-morbid FTD using [ $\left.{ }^{18} \mathrm{~F}\right]-\mathrm{FDG}$ PET [25]. Interestingly, patients with milder cognitive impairment showed less explicit frontal hypometabolism. These results confirm the hypothesis of a clinical continuum between both disorders and indicate that $\left[{ }^{18} \mathrm{~F}\right]$-FDG PET could be applied to determine the cognitive state of ALS patients. The remaining $90-95 \%$ of all ALS cases are sporadic (SALS). Although the presence of fALS causing gene mutations has been shown in some SALS cases and the existence of susceptibility genes in SALS has been suggested, the primary cause of the majority of ALS cases remains unraveled.

In analogy with many other major neurodegenerative diseases, such as Alzheimer's disease and Parkinson's disease (PD), the pathophysiology of ALS is considered a complex, multifactorial interaction of genetic, molecular and cellular mechanisms $[26,27]$. The main pathologic processes take place in the motor neuron cell bodies, the axons and at the neuromuscular junction and in the surrounding cells. Among the long list of possibly involved pathogenic pathways, several mechanisms are thought to be key players in the relentless degeneration of motor neurons. Oxidative stress, resulting from increased generation and accumulation of reactive oxygen species (ROS), is present in cerebrospinal fluid (CSF) and serum of ALS patients [28-30] which provides evidence for neurodegeneration due to oxidative damage. Mitochondrial DNA in the spinal cord of ALS patients shows elevated mutation rates [31] and these abnormalities are already present before symptom onset [32]. Furthermore, mutated TDP-43 and SOD1 can migrate to mitochondria and induce mitochondrial dysfunction as well $[33,34]$. The role of glutamate-mediated excitotoxicity and injury due to overstimulation by excitatory mediators, was suggested in ALS pathogenesis by detection of high glutamate levels in CSF $[35,36]$. The positive effect of the anti-glutamatergic drug Riluzole also supports the role of excitotoxicity in ALS pathogenesis. Protein-aggregates, a generally accepted pathological hallmark of neurodegenerative diseases, are mainly found in spinal motor neurons in ALS and can consist of cytostatin C, transferrin [37], neuro-filament rich hyaline aggregates [38, 39] or TDP$43[40,41]$. Interestingly, spreading of these TDP-43 containing inclusions was shown to be associated with disease progression through the neuropathological disease stages [42, 43]. Another important hallmark is chronic neuroinflammation, characterized by activation of microglia and astrocytes, a feature shown to correlate with disease progression $[44,45]$. These pathways offer potentially promising targets for non-invasive in vivo imaging of motor neuron degeneration in ALS, and may form targets for novel therapies, for which imaging can lead to proof-of-principle. 


\section{Additive value of in vivo imaging in ALS}

Since there is no diagnostic test with sufficient specificity and sensitivity available for ALS, diagnosis predominantly relies on the presentation of clinical symptoms listed in the revised El Escorial [46] and Awaji-Shima [47] criteria, supported by electrophysiological and genetic testing and sometimes neuroimaging. Nevertheless, the diagnostic process is associated with a significant uncertainty level due to limited sensitivity of the applied criteria, often resulting in diagnostic delay (up to 1 year) [48]. Incorporation of non-invasive in vivo imaging techniques, such as Positron Emission Tomography (PET), Single Photon Emission Computed Tomography (SPECT) and Magnetic Resonance Imaging (MRI), into the standard diagnostic regimen, might provide crucial additional and complementary disease information and may therefore increase the confidence level and the extent of early diagnosis [49].

Currently, the main role of neuroimaging remains limited to excluding structural pathologies which can cause symptoms similar to those of ALS, such as Kennedy's disease and X-linked spino-bulbar muscular atrophy, which may clinically present as ALS. Here, structural MRI is the primary investigation of choice. In two structural T2-weighed imaging studies however, this technique appeared to be neither sufficiently sensitive ( $76 \%$ and $90 \%$, respectively) nor specific ( $75 \%$ and $21 \%$, respectively) as a diagnostic tool $[50,51]$. Although more advanced MR techniques, such as diffusion tensor imaging (DTI) [52-54], voxel-based morphometry (VBM) [55] and resting state functional MRI (rs-fMRI) [56-58] have shown promising results and might be useful as non-invasive diagnostic markers, their true diagnostic potential remains to be elucidated. In 2010 however, Filippini et al. reported that multimodal MRI, combining fractional anisotropy, grey matter and radial diffusity measures, could discriminate ALS patients from healthy controls with an accuracy of $90 \%$, highlighting the potential of multimodel MRI as a diagnostic tool for ALS [59].

Radionuclide imaging techniques, such as PET and SPECT, may play a new role in earlier and more accurate ALS diagnosis and disease monitoring $[49,60]$. Targeting (via receptors, transporters, deposition proteins etc.) of key cellular pathways involved in ALS pathogenesis may visualize and quantify these ongoing processes, providing important additional information and allowing disease staging. Since the underlying pathologic processes might be ongoing long before symptom onset, these tracers might allow earlier (pre-symptomatic) diagnosis. Taken together, non-invasive in vivo imaging of the pathological disease hallmarks of ALS could further improve our insights on disease onset, pathogenesis and progression and might contribute to the design and evaluation of novel drugs and therapies, by monitoring their effects in vivo. 


\section{Radiotracers applied in ALS}

Although a small variety of both PET and SPECT tracers has been proposed to visualize disease specific changes $[49,60]$, the majority of published radionuclide imaging studies in ALS have used $\left[{ }^{18} \mathrm{~F}\right]-$ fluorodeoxyglucose ([18F]-FDG), visualizing cerebral glucose metabolism. Already in 1987, Dalakas et al. showed decreased $\left[{ }^{18} \mathrm{~F}\right]-\mathrm{FDG}$ uptake, indicating neuronal malfunctioning in the ALS brain [61]. Later, several groups confirmed hypometabolism in the primary motor cortex, supplementary motor cortex and premotor cortices but also in the frontal and parietal cortex. It was hypothesized that the degree of hypometabolism in the motor cortex correlates with disease duration, but conflicting results have been reported [62-64]. On the other hand, hypermetabolism was observed in the mesiotemporal cortex, cerebellum and upper brain stem [65]. Overall, diagnostic value analysis of $\left[{ }^{18} \mathrm{~F}\right]$-FDG PET versus a control population showed $90-95 \%$ sensitivity [66-68]. In the future, implementation of $\left[{ }^{18} \mathrm{~F}\right]-\mathrm{FDG}$ PET in the standard diagnostic work-up will result in large datasets, allowing multivariate analysis and identification of spatially distinct brain networks affected by neurodegeneration. Only very recently, Pagani et al. showed that spatial individual component analysis, which determines significant discriminative regions, in combination with multivariate analysis resulted in $99 \%$ accurate differentiation between patients and controls [69]. These results indicate that the degenerative process affects specific brain connections rather than isolated brain regions and are in line with a previously describes hypothesis of anterograde disease propagation along specific tracts [70]. In ALS with co-morbid cognitive impairment or FTD, prefrontal, anterior cingulate and insular hypometabolism was observed when compared with cognitively normal ALS patients $[71,64,25]$. As mentioned before, $\left[{ }^{18} \mathrm{~F}\right]$-FDG may also be a valuable prognostic tool as a predictor for cognitive impairment or FTD, which decreases survival $[72,73]$. A potential drawback of $\left[{ }^{18} \mathrm{~F}\right]-\mathrm{FDG}$ is that its uptake might not only represent neuronal activity but the signal is also derived from astrocytes. Furthermore, Pellerin and Magistretti showed that glutamate uptake in astrocytes stimulates glucose utilization, suggesting direct coupling between ongoing excitotoxicity and increased $\left[{ }^{18} \mathrm{~F}\right]$-FDG uptake [74].

A second indirect target applied to quantify brain dysfunction in ALS is cerebral blood flow (CBF). Using $\left[{ }^{15} \mathrm{O}\right] \mathrm{H}_{2} \mathrm{O}$ PET, $\left[{ }^{99 \mathrm{~m}} \mathrm{Tc}\right]-\mathrm{d}, 1-\mathrm{HMPO}$ (hexamethyl-propyleneamine oxime) SPECT or $\left.{ }^{99 \mathrm{~m}} \mathrm{Tc}\right]-\mathrm{ECD}$ (ethyl cysteinate diethylester) SPECT, a decrease in CBF has been observed in the primary motor cortex of ALS patients $[75,76]$, as well as impaired CBF in the frontal lobes of ALS patients with co-morbid cognitive involvement [77]. The extent of cortical changes, as determined by [ ${ }^{99 \mathrm{~m} T c]}$-ECD SPECT, correlated with the degree of functional disability and the location of motor impairment [78]. 
To investigate the hypothesis of mutual pathogenic processes in both ALS and Parkinson's Disease, imaging of the dopaminergic nigrostriatal tract, using $\left[{ }^{18} \mathrm{~F}\right]-3,4$-dihydroxyphenylalanine $\left(\left[{ }^{18} \mathrm{~F}\right]-\mathrm{DOPA}\right)$

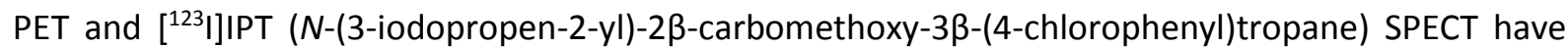
shown reduced striatal presynaptic dopaminergic functioning in ALS patients when compared to healthy volunteers, suggesting subclinical disturbance of the nigrostriatal tract. However, contrasting results were reported on whether this decrease in tracer uptake correlates with disease duration [7981].

Flumazenil is an antagonist of the gamma-amino butyric acid, subtype A (GABA-A) receptor that binds its benzodiazepine subunit. Since the receptor is expressed on both pyramidal cells and interneurons of the cerebral cortex, $\left[{ }^{11} \mathrm{C}\right]$-Flumazenil is a potential in vivo marker for neuronal loss and potential GABA-ergic inhibitory dysfunction in ALS and therefore, provides important evidence for inhibitory failure with potential consequent excitotoxicity as pathologic hallmark. Several imaging studies using $\left[{ }^{11} \mathrm{C}\right]$-Flumazenil have been performed in ALS. In 2000, Lloyd et al. showed significantly reduced tracer distribution volumes in both motor and extra-motor regions of the ALS brain [82]. Furthermore, the pattern of reduced $\left[{ }^{11} \mathrm{C}\right]$-Flumazenil distribution volumes in patients with $\mathrm{fALS}$, harboring the D90A mutation in the SOD1 gene, differed from the pattern observed in SALS cases [83], in which a correlation between decreased tracer uptake and poorer verbal fluency was reported [84]. Although ALS and PLS show similar overall $\left[{ }^{11} \mathrm{C}\right]$-Flumazenil patterns when compared to healthy controls, PLS patients showed more extensive neurodegeneration in the primary motor cortex and anterior cingulate cortex [85]. Therefore, $\left[{ }^{11} \mathrm{C}\right]$-Flumazenil was hypothesized to be useful to discriminate between ALS and PLS.

In 2005, Turner et al. investigated the distribution of $\left[{ }^{11} \mathrm{C}\right]-\mathrm{WAY} 100635$ (N-[2-[4-(2-methoxyphenyl)-1piperazinyl]ethyl]- $N$-(2-pyridyl)cyclohexanecarboxamide), an antagonist for the serotonin $1 \mathrm{~A}$ (5-HT1A) receptor in ALS patients. $\left[{ }^{11} \mathrm{C}\right]$-WAY100635 PET revealed widespread cerebral decrease of tracer uptake in both motor- and extra-motor regions of the ALS brain when compared to healthy controls, with the most prominent decrease in frontotemporal regions [86]. These results suggest potential involvement of the serotonergic system in ALS pathogenesis.

\section{Promising novel targets and tracers}

\section{Neuroinflammation}


Chronic neuroinflammation is characterized by activated microglia (gliosis) and astrocytes (astrocytosis), and is a common feature in several neurodegenerative diseases. During the past decade, great attention is given to the involvement of this inflammatory response in ALS pathogenesis and progression $[87,44]$. As resident macrophages of the CNS, microglia are involved in the innate immune response and turn into their activated state in case of tissue damage, pathogen invasion or protein aggregation. Initially, neuroinflammation is a protective mechanism prohibiting motor neuron death by stimulating tissue repair. In more advanced disease stages however, this protective immune response shifts towards a sustained, neurotoxic inflammatory condition, resulting in a vicious and destructive cycle of motor neuron death, which contributes to rapid disease progression [88]. Imaging of activated microglia may be a valuable diagnostic marker both at onset and during progression of neurodegeneration. It has been shown that neuroinflammation is already ongoing before symptom onset $[89,90]$, indicating its potential as a marker of the disease in its early stages.

Microglia and astrocytes express various cell surface receptors, cell signaling molecules and mitochondrial membrane receptors, involved in their normal function and regulation. When microglia turn into an activated state, the expression of some of these receptors is upregulated. This constitutes an ideal candidate target for both imaging and potentially also therapy, as neuroinflammation levels are absent or very low in healthy tissue and highly elevated in pathological conditions.

\section{Translocator protein (peripheral benzodiazepine receptor)}

The $18 \mathrm{kDa}$ translocator protein (TSPO), previously known as the peripheral benzodiazepine receptor, is located on the outer mitochondrial membrane of microglia, where it is part of the mitochondrial permeability transition pore. Although the exact function is still unknown, TSPO is involved in a variety of cellular processes such as proliferation and apoptosis [91]. Furthermore, TSPO enables cholesterol transport over the mitochondrial membrane and is therefore associated with steroid production [92]. TSPO is hardly expressed in healthy CNS while expression levels are substantially elevated in activated glial cells [93]. At this moment, TSPO is the most extensively explored marker for neuroinflammation PET. However, the Ala147Thr TSPO polymorphism results in three distinct affinity patterns (high affinity binders ( $H A B)$, low affinity binders ( $L A B)$ and mixed affinity binders (MAB)), showing significant differences in tracer uptake $[94,95]$. Therefore, genotyping is required to allow reliable quantification and interpretation of TSPO scans.

The first tracer applied for TSPO imaging was the enantiomeric isoquinoline carboxamide derivative $\left[{ }^{11} \mathrm{C}\right]-(\mathrm{R})-\mathrm{PK} 11195$ [96]. Already in the 1980's, this non-benzodiazepine TSPO ligand was characterized and validated as a promising tracer for neuronal damage [97-100]. Afterwards, $\left[{ }^{11} \mathrm{C}\right]-(\mathrm{R})-\mathrm{PK} 11195$ was 
consistently used for imaging of neuroinflammation in disorders such as stroke [101, 102], Alzheimer's disease [103], and MS [104]. In ALS, post-mortem autoradiographic analysis revealed increased $\left[{ }^{3} \mathrm{H}\right]-$ (R)-PK11195 accumulation in the spinal cord [105] which is in line with previous immunohistochemical analyses [106, 107]. In 2004, Turner et al. [108] reported significantly increased $\left[{ }^{11} C\right]-(R)-P K 11195$ uptake in the motor cortex, pons and dorsolateral prefrontal cortex of ALS patients when compared to healthy controls. Furthermore, they found a positive correlation between tracer uptake in the motor cortex and UMN involvement. Despite these promising results on group level, individual tracer uptake was variable with strongly overlapping binding potentials between patients and healthy volunteers, and did not correlate with the degree of motor neuron impairment (ALS-FRS) nor with disease duration. As $\left[{ }^{11} \mathrm{C}\right]-(\mathrm{R})$-PK11195 displays high non-specific binding and limited target-to-background ratio, improved potential radiotracers are being tested.

Zürcher et al. successfully applied $\left[{ }^{11} \mathrm{C}\right]-\mathrm{PBR} 28$, a phenoxy-arylacetamide derivative, to quantify neuroinflammation in ALS patients [109]. In this study, increased $\left[{ }^{11} \mathrm{C}\right]-$ PBR28 uptake was found in the bilateral motor cortices, including the primary and supplementary motor cortices of ALS patients when compared to controls. Standardized Uptake Values (SUV) of the right precentral gyrus were positively correlated with UMN involvement, which is in line with the observations of Turner et al. [108], and negatively correlated with ALS-FRS. Although the sample size was rather small, these findings are promising since abnormal findings were present in all individual subjects with little overlap with controls.

$\left[{ }^{18} \mathrm{~F}\right] \mathrm{DPA}-714$ is a pyrazolo[1,5-a]pyrimidine derivative with improved binding affinity compared to $\left[{ }^{11} \mathrm{C}\right]-(\mathrm{R})-\mathrm{PK} 11195[110,111]$. The tracer was tested in various preclinical models of neuroinflammation, such as mice with cerebral ischemia and chemically induced brain injury, showing significantly increased, TSPO-mediated tracer binding in affected brain regions [110-112]. In healthy humans, brain uptake peaked five minutes post-injection and most of the tracer was localized in the thalamus [113]. In 2012, Corcia and co-workers compared $\left[{ }^{18} \mathrm{~F}\right] \mathrm{DPA}-714$ distribution in ALS patients with tracer distribution in healthy volunteers [114]. They reported that microglial activation is not limited to the motor areas but was also present in the temporal cortex which is at odds with frontal findings in Turner's study [108]. The authors hypothesized that these discrepancies might be explained by differences in location and extent of microglial activation over the course of disease.

\section{P2X7 receptor}

A novel target of high interest for neuroinflammation imaging is the P2X7 receptor, which belongs to the purinergic receptor family (P2), consisting of an ionotropic (P2X) and a metabotropic (P2Y) 
subfamily. The P2X subfamily consists of low affinity, ATP-gated, non-selective cation channels, selectively expressed on cells originating from the hematopoietic cell lineage, such as microglia, astrocytes and Schwann cells, and is implicated in a variety of pathophysiological CNS functions [115]. P2X7 requires high ATP concentration for its activation and, upon continuous activation, the ion channel changes its conformation towards a membrane pore, permeable to molecules up to $9 \mathrm{kDa}$ without receptor desensitization [116]. When cell injury or tissue damage occurs within the CNS, extracellular ATP levels are rising, leading to P2X7 receptor activation and secretion of proinflammatory mediators, such as interleukin- $\beta$ (IL- $\beta$ ) and tumor necrosis factor- $\alpha$ (TNF- $\alpha$ ), from activated microglia, causing receptor shift towards the pore state and induction of a destructive inflammatory cycle, contributing to neurodegeneration [117]. Yiangiou et al. showed upregulated P2X7 expression in microglia of ALS patients using immunohistochemistry [118]. However, experimental evidence in SOD-1 mutated P2X7 KO mice suggests a protective role for $\mathrm{P} 2 \mathrm{X7}$ at some point in ALS pathogenesis [119], indicating a dual effect of the receptor on disease progression depending on disease stage. Next to neuroinflammation, $\mathrm{P} 2 \mathrm{X} 7$ receptor signaling has been implicated in excitatory synaptic transmission regulation by modulating release of neurotransmitters, such as glutamate and GABA, from astrocytes $[120,121]$. Since P2X7 is related to neuroinflammation and excitotoxicity, both generally accepted key pathogenic mechanisms of neurodegenerative disease, they are considered highly suitable targets for therapeutic exploitation and imaging. Several P2X7 antagonists have been developed, patented and tested over the last two decades [122-124].

Up until now, most published studies evaluating novel P2X7 antagonists have used tritiated compounds to perform mechanistic receptor studies in vitro [125-128]. All tested molecules showed high receptor affinity and, saturable and receptor-mediated binding. Nevertheless, none of these molecules was tested in the clinical setting. An important obstacle towards clinical translation of P2X7 targeting PET tracers is the inter-species difference in receptor binding affinity for rat, mouse and human receptors [129]. Therefore, the use of humanized animal models and human in vivo imaging studies are required. Recently, Ory et al. reported the preclinical evaluation of $\left[{ }^{11} \mathrm{C}\right]-\mathrm{JNJ}-54173717$ in a humanized rat model and non-human primates [130]. The tracer showed nanomolar affinity for both the rat and human receptor $\left(\mathrm{IC}_{50}=7.6\right.$ and $4.2 \mathrm{nM}$, respectively) with negligible non-specific binding. High receptor-mediated tracer accumulation was observed in the hP2X7 expressing striatum of rats and homogenous specific tracer uptake was observed throughout the brain of non-human primates.

Janssen et al. reported the first preclinical in vivo evaluation of the P2X7 receptor antagonist-based PET tracer $\left[{ }^{11} \mathrm{C}\right]-\mathrm{A}-740003$ [131]. Despite promising in vitro results, limited brain uptake was observed at all time points. The authors argued that this might be explained by blood brain barrier blocking or 
by low receptor expression in healthy brain and additional studies in neuroinflammation models will have to elucidate the tracers potential for neuroinflammation imaging. Given its excellent affinity for $\mathrm{hP2X7}\left(\mathrm{IC}_{50}=3 \mathrm{nM}\right)$ [132] and proven safety and tolerability in humans [133], $\left[{ }^{11} \mathrm{C}\right] \mathrm{GSK} 1482160$ is an attractive candidate for in vivo visualization of neuroinflammation by P2X7 targeting. Therefore, clinical PET studies should be performed in ALS patients and healthy controls to determine its potential as $\mathrm{P} 2 \mathrm{X} 7$ tracer. Next to $\mathrm{P} 2 \mathrm{X} 7$, other members of the purinergic receptor family, such as $\mathrm{P} 2 \mathrm{X} 4$ and $\mathrm{P} 2 \mathrm{Y} 12$ are involved in the pathogenesis of ALS, and therefore constitute further potential targets for in vivo imaging.

\section{Other potential targets and tracers}

Cyclo-oxygenase 2 (COX-2) is an inducible enzyme with a key role in the neuroinflammatory cascade, with low levels in healthy tissue and both central and peripheral nervous system upregulation upon inflammation induction [134]. A seven-fold and four-fold upregulations of respectively COX-2 mRNA and protein levels was observed in spinal cord of SOD1 mice and in human spinal cord slices postmortem $[118,135]$. Furthermore, the level of COX-2 upregulation matched with the extent of motor neuron loss and administration of COX-2 inhibitors has been suggested to delay symptom onset in a transgenic mouse model of ALS $[136,137]$. These findings clearly highlight the potential value of COX2 as a target for therapy and disease monitoring. A variety of COX-2 inhibitor based radiotracers, such as $\left[{ }^{11} \mathrm{C}\right]$ celecoxib and ${ }^{11} \mathrm{C}$ or ${ }^{18} \mathrm{~F}$ labeled celecoxib derivatives, have been described $[138,139]$. Unfortunately, most of these tracers showed poor in vivo specificity and the search for a suitable COX2 tracer is still ongoing.

Mono-amine oxidase (MAO)-B is an enzyme, responsible for oxidative deamination of mono-amines such as adrenaline, dopamine and serotonin, and is found mainly in astrocytes and serotonergic neurons. Since neuro-inflammation consists of both microgliosis and astrocytosis, MAO-B represents a potential imaging target. Already in 1995, Fowler et al. showed the possibility to image MAO-B activity using $\left[{ }^{11} \mathrm{C}\right]$-deprenyl-D2 $\left(\left[{ }^{11} \mathrm{C}\right]-\mathrm{DED}\right)$, a selective and irreversible MAO-B inhibitor [140]. Postmortem in vitro autoradiography studies on brain slices of ALS patients revealed increased $\left[{ }^{3} \mathrm{H}\right]-\mathrm{DED}$ accumulation in the motor neuron laminae and corticospinal tracts, which correlated with astrocyte count in these brain areas [141]. Furthermore, increased $\left[{ }^{11} C\right]$-DED uptake, associated with astrocytosis, was shown in a complex ALS case [142], confirming the tracers potential as astrocytosis marker. Johansson et al. showed increased tracer uptake in the pons and white matter tracts of ALS patients when compared to healthy volunteers, possibly representing astrocytosis. However, the sample size was rather small and the differences in SUV values between patients and healthy controls were not significantly different [143]. 
Type 2 cannabinoid receptors (CB2R) belong to the rhodopsin-like family class A of G-protein coupled receptors and are expressed on cells of the immune system. Since CB2R is upregulate in the spinal cord of ALS patients [118] and cannabinoid action has been shown to downregulate NO production by microglia [144], CB2R exhibits potential as a marker and as a therapeutic target for ALS and other neurodegenerative diseases involving neuroinflammation. Several ${ }^{11} \mathrm{C}$ and ${ }^{18} \mathrm{~F}$ labeled $\mathrm{CB} 2 \mathrm{R}$ tracers have been recently described. $\left[{ }^{11} \mathrm{C}\right] \mathrm{NE} 40$, a 2-oxoquinoline derivative, is shown to exhibit specific and irreversible in vivo binding to human CB2R $[145,146]$, but failed to show a neuroinflammation signal in $A D$ (Ahmad et al, in press). $\left[{ }^{11} \mathrm{C}\right] \mathrm{KD} 2$, a 4- oxoquinoline derivative displayed receptor mediated binding in ALS spinal cord, as shown by in vitro autoradiography [147]. Slavik et al. recently reported two KD-2 based radiotracers ([11C]RSR-056 and $\left.\left[{ }^{11} \mathrm{C}\right] \mathrm{RS}-016\right)$ with improved binding affinities towards CB2R and increased uptake in a murine neuroinflammation model $[148,149]$.

\section{Excitotoxicity}

Excitotoxicity by excessive glutamate signaling is considered a key mechanism in neurodegenerative disorders and, in particular, in ALS pathogenesis. Interestingly, excitotoxicity seems connected to other key pathological mechanisms, such as neuroinflammation and protein aggregation, through increased $\left[\mathrm{Ca}^{2+}\right]$ influx by activation of specific receptors, such as $\mathrm{P} 2 \mathrm{X} 7$, resulting in a variety of cellular processes [150]. Therefore, specific components of the glutamatergic cascade could be of interest to exploit for imaging and potentially drug therapy.

The family of glutamate receptors contains ionotropic ligand-gated ion channels and three groups of metabotropic GTP-gated receptors. The metabotropic glutamate receptor subtype 5 (mGLuR5) is part of the group 1 mGluRs and exhibits a variety of functions within the CNS. They are abundantly expressed on healthy neurons throughout the spinal cord while expression levels on non-reactive glial cells are low. However, these expression levels showed a seven-fold increase in both grey and white matter, as determined by immunohistochemistry, when glial cells shift towards their reactive state [151]. ([ $\left.{ }^{18} \mathrm{~F}\right] 3$-fluoro-5-(2-pyridylethynyl)benzonitrile) [ $\left.{ }^{18} \mathrm{~F}\right] \mathrm{FPEB}$ PET is a potent and selective mGluR5 inhibitor that generates a stable and long-lived PET signal which is in line with the location of mGluR5 expression, as determined by ex vivo autoradiography [152]. Recent work of Brownell et al. described the in vivo visualization of enhanced mGluR5 expression in the brain and, to a lesser extent, in the spinal cord of SOD-1 mutated mice, using $\left[{ }^{18}\right.$ F]FPEB PET [153]. Interestingly, $\left[{ }^{18} \mathrm{~F}\right]$ FPEB uptake increased over the course of disease along with the level of neuro-inflammation, as assessed by parallel $\left.{ }^{[11} \mathrm{C}\right]$ PBR28 PET. These results clearly indicate a close connection or even an alliance between 
excitotoxicity and neuro-inflammation in ALS pathogenesis, thereby supporting the interplay between the key pathological mechanisms, as described by Sperlágh et al. [150].

The second member of the group $1 \mathrm{mGluR}$ subfamily is the metabotropic glutamate receptor subtype 1 (mGluR1), which is involved in a variety of intracellular signaling systems. As for mGluR5, activation of mGluR1 has been linked to excessive and abnormal glutamate production, suggesting a role in ALS pathogenesis [154]. Downregulation of mGluR1 in SOD-1 mutated, ALS prone mice resulted in later disease onset and progression, and prolonged survival [155]. Furthermore, these mice showed less activated microglia and astrocytes subscribing the link between excitotoxicity and neuroinflammation and the involvement of mGluR1 in ALS pathogenesis. Therefore, also mGluR1 is a possible target for non-invasive visualization of ongoing neurodegeneration in ALS. Unfortunately, the development of suitable mGluR1 PET tracers has been challenging because of cross-reactivity of most developed tracers with mGluR5 $[156,157]$. Recently, Zanotti-Fregonara et al. investigated the in vivo use of $\left[{ }^{18} \mathrm{~F}\right]-$ FIMX in the human brain. $\left[{ }^{18} \mathrm{~F}\right]-\mathrm{FIMX}$ shows fast brain kinetics and distribution volumes could be estimated [158].

\section{Synaptic density}

Altered synaptic density is a pathological feature associated with various neurodegenerative and psychiatric disorders [159-162]. Since excitotoxicity and GABA-ergic inhibitory dysfunction are key players in ALS, disruption of synaptic transmission may be involved in its pathogenesis. Indeed, early synaptic rearrangement, with inhibitory synapse bouton loss and excitatory synapse bouton gain, was observed in motor neurons of SOD-1 mutated mice and favored disease progression [163]. Another study showed that UBQLN2 (a gene linked to ALS and FTD) transgenic mice, developed inclusions associated with synaptic dysfunction and cognitive decline [164]. Up until now, quantification of synaptic density is performed on brain sections obtained from autopsy or resection using antibodies targeting proteins located on synaptic vesicles, such as synaptophysin [165]. However, in vivo quantification of synaptic density could provide important real-time information and might improve early diagnosis. Synaptic vesicle glycoprotein $2 \mathrm{~A}$ (SV2A) is a transmembrane protein found in all vertebrate synaptic vesicles of both excitatory and inhibitory synapses and is hypothesized to be a key player in exocytosis and neurotransmission control, although its exact role remains unclear [166]. Several SV2A targeting tracers, such as $\left[{ }^{18} \mathrm{~F}\right]-\mathrm{UCB}-\mathrm{H},\left[{ }^{11} \mathrm{C}\right]-\mathrm{UCB}-\mathrm{A}$ and $\left[{ }^{11} \mathrm{C}\right]-\mathrm{UCB}-\mathrm{J}$ have been described [167-169], with $\left[{ }^{11} \mathrm{C}\right]-\mathrm{UCB}-\mathrm{J}$ showing the best characteristics for in vivo brain imaging, namely: excellent brain uptake (with the highest uptake values in striatum and cortex), rapid kinetics and metabolism, and suitable time-activity curves [168]. Very recently, Finnema et al. published a first-in-human study in which they confirmed SV2A specific tracer binding and observed that the tracer can indeed visualize 
changes in synaptic density in epilepsy patients [170]. Taken together, these observations suggest that SV2A targeting PET tracers harbor great potential for early diagnosis and therapy monitoring of neurodegenerative disorders.

\section{Protein aggregation}

Up to now, there are no tracers available for specific protein aggregates in the brain of ALS patients, such as TDP-43, SOD1 and neurofilament deposits [171-174], but several initiatives are being undertaken such as the FTD biomarker initiative from the Association for Frontotemporal Degeneration (http://www.theaftd.org/research/ftd-biomarkers-initiative). Visualization of amyloidbeta deposits in ALS has been investigated concerning a suggested link between ALS and Alzheimer's disease [175]. This relation between ALS and amyloid precursor protein was observed in rodent models and recent post-mortem immunohistochemical analysis have also shown amyloid deposition in 35$50 \%$ of all ALS patients, even without co-morbid dementia $[176,175]$. Currently, there are 3 published case reports of ALS patients with co-morbid dementia scanned with $\left[{ }^{11} \mathrm{C}\right]-\mathrm{PIB}$ (Pittsburgh Compound B). These reports suggest a potential role for $\left[{ }^{11} \mathrm{C}\right]-\mathrm{PIB}$ PET in the discrimination of various neurodegenerative proteinopathies such as Alzheimer's and ALS with co-morbid frontotemporal dementia (FTD) $[142,177]$. Very recently, Matías-Guiu et al. studied amyloid deposition in a cohort of ALS patients using $\left[{ }^{18} \mathrm{~F}\right]$-florbetaben PET. However, only a small number of patients showed increased tracer uptake in a variety of brain regions and the detected amyloid load in ALS patients was comparable to amyloid load observed in age-matched controls [178]. Therefore, cautious interpretation of these data and further investigations are required.

\section{Mitochondrial dysfunction and oxidative stress}

Oxidative stress and mitochondrial dysfunction are both considered key players in ALS pathogenesis $[179,180]$. These two processes cannot be considered separate entities. Oxidative stress arises from an imbalance between ROS production and elimination in which the balance is tilted away from elimination and towards excessive production. Damage to mitochondrial respiratory chain proteins can induce an over-reductive state, characterized by electron leakage leading to dramatically increased ROS production. Since excessive ROS accumulation is observed in the CSF of ALS patients, mitochondrial over-reductive state (and its consequent oxidative stress) might be a promising novel target in ALS imaging.

$\left[{ }^{62} \mathrm{Cu}\right]$-ATSM $\left(\left[{ }^{62} \mathrm{Cu}\right]\right.$ diacetyl-bis $\left(N^{4}\right.$-methylthiosemicarbazone $)$ is a PET radioligand that will be retained in cells displaying redox imbalance, due to copper reduction to $\mathrm{Cu}(\mathrm{I})$ [181]. Therefore, it is capable of visualizing cells with mitochondrial dysfunction, such as hypoxic and anoxic cells, seen their 
intracellular overreductive state. However, the tracer does not visualize cells harboring sufficient defense mechanisms to counteract ROS production such as prostate cancer cells, which apply the fatty acid synthesis pathway to improve their redox balance. Therefore, inhibition of this pathway results in a significant increase in $\left[{ }^{64} \mathrm{Cu}\right]-A T S M$ uptake in prostate cancer cells, highlighting the effect of ROS defense mechanisms on tracer uptake in hypoxic cells [182]. In vitro characterization showed increased tracer accumulation in cells in the overreductive state due to mitochondrial dysfunction when compared to normal cells $[183,184]$ and the feasibility of in vivo oxidative stress detection using this tracer, was shown in patients suffering from mitochondrial disease [185]. In 2011, Ikawa et al. reported increased striatal $\left[{ }^{62} \mathrm{Cu}\right]-\mathrm{ATSM}$ uptake in patients with PD when compared to healthy controls, the tracer showed rapid blood brain barrier penetration and tracer accumulation correlated linearly with disease progression [186]. More recently, the same group showed elevated normalized SUV's in cortical regions, such as the motor cortex bilaterally and the right superior parietal lobe, in 12 ALS patients. Furthermore, increased oxidative stress in these regions was associated with the degree of motor neuron degeneration, represented in the ALS-FRS [187]. Next to its potential for imaging, $\left[{ }^{\mathrm{Nat}} \mathrm{Cu}\right]-\mathrm{ATSM}$ has shown potential as a therapeutic agent in mouse models of ALS. Treatment with $\left[{ }^{\mathrm{Nat}} \mathrm{Cu}\right.$ ]-ATSM effectively protected ALS-prone, SOD1 mutated mice from developing ALS, with an extended survival of 18 months on average. In other studies using different SOD1 mutated mouse models [ $\left.{ }^{\mathrm{Nat}} \mathrm{Cu}\right]-\mathrm{ATSM}$ treatment extended their life with $15 \%$ and $26 \%$, respectively [188-190]. Taken together, these observations highlight the promising character of CU-ATSM in ALS therapy and diagnostics.

\section{Conclusions and future prospects}

ALS is a multi-system disorder with a complex underlying pathophysiology rendering adequate diagnosis and management a real challenge. Therefore, implementation of non-invasive in vivo imaging in the diagnostic regimen might improve accuracy of early diagnosis. Currently, $\left[{ }^{18} \mathrm{~F}\right]-\mathrm{FDG}$ PET is a promising indirect measure of neuronal dysfunction in ALS that might allow identification of specifically affected connections between brain regions and spatially distinct networks with significant discriminative values. Since neurodegeneration is a process of networks rather than isolated regions, brain network analysis might significantly improve accurate diagnosis. Next to determination of the spatial metabolic signature, in vivo visualization of the multiple underlying pathological processes is likely to aid in gaining directly relevant information on disease onset or progression. In the past decade, several novel radiotracers have been described to visualize, among others, neuroinflammation and excitotoxicity (table 1). For other central molecular processes, involved in ALS pathogenesis such as protein deposition (e.g. TDP-43), tracer development in currently ongoing. In families harboring 
specific ALS-causing mutations, imaging of the pathological process initiated by this mutation could allow early disease detection and even prevention when performed longitudinally. Combined application of tracers, targeting different pathological processes, might provide novel insights in disease patterns specific for ALS, PLS or other mimic syndromes, thereby facilitating their differentiation. Finally, clinical implementation of these tracers will allow non-invasive evaluation of novel drugs, counteracting specific pathological pathways, and improve detailed disease progression monitoring. Although not discussed in depth in this manuscript, more widespread implementation of simultaneous hybrid imaging systems, such as PET-MR scanners, might also aid in developing multiparametric markers and in functional connectivity assessment for further characterization of affected brain networks.

\section{Compliance with Ethical Standards}

Funding: PVD and KVL hold a senior clinical investigator ship from FWO-Vlaanderen. PVD is supported by grants from the Opening the Future Fund (KU Leuven), the Interuniversity Attraction Poles (IUAP) program P7/16 of the Belgian Federal Science Policy Office, the Alzheimer Research Foundation (SAOFRA), the Flemish Government initiated Flanders Impulse Program on Networks for Dementia Research (VIND), the Fund for Scientific Research Vlaanderen (FWO-Vlaanderen), under the frame of E-RARE-2 (PYRAMID) and JPND (STRENGTH and RiMod-FTD), the IWT, the ALS liga België and the Thierry Latran foundation. For ALS and neuroinflammation research KVL is supported by the European Union's Seventh Framework Programme (FP7/2007-2013) under Grant Agreement no. HEALTH-F2-2011278850 (INMiND). Conflict of interest: all authors declare that they have no conflict of interest. Ethical approval: this article does not contain any studies with animals or human participants, performed by any of the authors. 


\section{References}

1. Kiernan MC, Vucic S, Cheah BC, Turner MR, Eisen A, Hardiman O et al. Amyotrophic lateral sclerosis. Lancet. 2011;377(9769):942-55. doi:10.1016/S0140-6736(10)61156-7.

2. Turner MR, Swash M. The expanding syndrome of amyotrophic lateral sclerosis: a clinical and molecular odyssey. J Neurol Neurosurg Psychiatry. 2015;86(6):667-73. doi:10.1136/jnnp-2014308946.

3. Leigh PN, Abrahams S, Al-Chalabi A, Ampong MA, Goldstein LH, Johnson J et al. The management of motor neurone disease. J Neurol Neurosurg Psychiatry. 2003;74 Suppl 4:iv32-iv47.

4. Laferriere F, Polymenidou M. Advances and challenges in understanding the multifaceted pathogenesis of amyotrophic lateral sclerosis. Swiss Med Wkly. 2015;145:w14054. doi:10.4414/smw.2015.14054.

5. Talbot K. Motor neuron disease: the bare essentials. Pract Neurol. 2009;9(5):303-9. doi:10.1136/jnnp.2009.188151.

6. Fumagalli E, Funicello M, Rauen T, Gobbi M, Mennini T. Riluzole enhances the activity of glutamate transporters GLAST, GLT1 and EAAC1. Eur J Pharmacol. 2008;578(2-3):171-6. doi:10.1016/j.ejphar.2007.10.023.

7. Kretschmer BD, Kratzer U, Schmidt WJ. Riluzole, a glutamate release inhibitor, and motor behavior. Naunyn Schmiedebergs Arch Pharmacol. 1998;358(2):181-90.

8. Wang SJ, Wang KY, Wang WC. Mechanisms underlying the riluzole inhibition of glutamate release from rat cerebral cortex nerve terminals (synaptosomes). Neuroscience. 2004;125(1):191-201. doi:10.1016/j.neuroscience.2004.01.019.

9. Lacomblez L, Bensimon G, Leigh PN, Guillet P, Meininger V. Dose-ranging study of riluzole in amyotrophic lateral sclerosis. Amyotrophic Lateral Sclerosis/Riluzole Study Group II. Lancet. 1996;347(9013):1425-31.

10. Bensimon G, Lacomblez L, Meininger V. A controlled trial of riluzole in amyotrophic lateral sclerosis. ALS/Riluzole Study Group. N Engl J Med. 1994;330(9):585-91. doi:10.1056/NEJM199403033300901.

11. Gordon PH, Cheung YK, Levin B, Andrews H, Doorish C, Macarthur RB et al. A novel, efficient, randomized selection trial comparing combinations of drug therapy for ALS. Amyotroph Lateral Scler. 2008;9(4):212-22. doi:10.1080/17482960802195632.

12. Beleza-Meireles A, Al-Chalabi A. Genetic studies of amyotrophic lateral sclerosis: controversies and perspectives. Amyotroph Lateral Scler. 2009;10(1):1-14. doi:10.1080/17482960802585469.

13. Rosen DR. Mutations in $\mathrm{Cu} / \mathrm{Zn}$ superoxide dismutase gene are associated with familial amyotrophic lateral sclerosis. Nature. 1993;364(6435):362. doi:10.1038/364362c0.

14. Kwiatkowski TJ, Jr., Bosco DA, Leclerc AL, Tamrazian E, Vanderburg CR, Russ C et al. Mutations in the FUS/TLS gene on chromosome 16 cause familial amyotrophic lateral sclerosis. Science. 2009;323(5918):1205-8. doi:10.1126/science.1166066.

15. Vance C, Rogelj B, Hortobagyi T, De Vos KJ, Nishimura AL, Sreedharan J et al. Mutations in FUS, an RNA processing protein, cause familial amyotrophic lateral sclerosis type 6 . Science. 2009;323(5918):1208-11. doi:10.1126/science.1165942.

16. Sreedharan J, Blair IP, Tripathi VB, Hu X, Vance C, Rogelj B et al. TDP-43 mutations in familial and sporadic amyotrophic lateral sclerosis. Science. 2008;319(5870):1668-72. doi:10.1126/science.1154584.

17. Byrne S, Elamin M, Bede P, Shatunov A, Walsh C, Corr B et al. Cognitive and clinical characteristics of patients with amyotrophic lateral sclerosis carrying a C9orf72 repeat expansion: a population-based cohort study. Lancet Neurol. 2012;11(3):232-40. doi:10.1016/S1474-4422(12)70014-5.

18. Chio A, Borghero G, Restagno G, Mora G, Drepper C, Traynor BJ et al. Clinical characteristics of patients with familial amyotrophic lateral sclerosis carrying the pathogenic GGGGCC hexanucleotide repeat expansion of C9ORF72. Brain. 2012;135(Pt 3):784-93. doi:10.1093/brain/awr366. 
19. Millecamps S, Boillee S, Le Ber I, Seilhean D, Teyssou E, Giraudeau M et al. Phenotype difference between ALS patients with expanded repeats in C9ORF72 and patients with mutations in other ALSrelated genes. J Med Genet. 2012;49(4):258-63. doi:10.1136/jmedgenet-2011-100699.

20. Lomen-Hoerth C, Anderson T, Miller B. The overlap of amyotrophic lateral sclerosis and frontotemporal dementia. Neurology. 2002;59(7):1077-9.

21. Seelaar H, Rohrer JD, Pijnenburg YA, Fox NC, van Swieten JC. Clinical, genetic and pathological heterogeneity of frontotemporal dementia: a review. J Neurol Neurosurg Psychiatry. 2011;82(5):47686. doi:10.1136/jnnp.2010.212225.

22. DeJesus-Hernandez M, Mackenzie IR, Boeve BF, Boxer AL, Baker M, Rutherford NJ et al. Expanded GGGGCC hexanucleotide repeat in noncoding region of C9ORF72 causes chromosome 9p-linked FTD and ALS. Neuron. 2011;72(2):245-56. doi:10.1016/j.neuron.2011.09.011.

23. Ringholz GM, Appel SH, Bradshaw M, Cooke NA, Mosnik DM, Schulz PE. Prevalence and patterns of cognitive impairment in sporadic ALS. Neurology. 2005;65(4):586-90. doi:10.1212/01.wnl.0000172911.39167.b6.

24. Neary D, Snowden JS, Mann DM. Cognitive change in motor neurone disease/amyotrophic lateral sclerosis (MND/ALS). J Neurol Sci. 2000;180(1-2):15-20.

25. Canosa A, Pagani M, Cistaro A, Montuschi A, lazzolino B, Fania P et al. 18F-FDG-PET correlates of cognitive impairment in ALS. Neurology. 2016;86(1):44-9. doi:10.1212/WNL.0000000000002242.

26. Ferraiuolo L, Kirby J, Grierson AJ, Sendtner M, Shaw PJ. Molecular pathways of motor neuron injury in amyotrophic lateral sclerosis. Nat Rev Neurol. 2011;7(11):616-30. doi:10.1038/nrneurol.2011.152.

27. Shaw PJ. Molecular and cellular pathways of neurodegeneration in motor neurone disease. J Neurol Neurosurg Psychiatry. 2005;76(8):1046-57. doi:10.1136/jnnp.2004.048652.

28. Lyras L, Evans PJ, Shaw PJ, Ince PG, Halliwell B. Oxidative damage and motor neurone disease difficulties in the measurement of protein carbonyls in human brain tissue. Free Radic Res. 1996;24(5):397-406.

29. Mitsumoto H, Santella RM, Liu X, Bogdanov M, Zipprich J, Wu HC et al. Oxidative stress biomarkers in sporadic ALS. Amyotroph Lateral Scler. 2008;9(3):177-83. doi:10.1080/17482960801933942.

30. Simpson EP, Henry YK, Henkel JS, Smith RG, Appel SH. Increased lipid peroxidation in sera of ALS patients: a potential biomarker of disease burden. Neurology. 2004;62(10):1758-65.

31. Wiedemann FR, Manfredi G, Mawrin C, Beal MF, Schon EA. Mitochondrial DNA and respiratory chain function in spinal cords of ALS patients. J Neurochem. 2002;80(4):616-25.

32. Kong J, Xu Z. Massive mitochondrial degeneration in motor neurons triggers the onset of amyotrophic lateral sclerosis in mice expressing a mutant SOD1. J Neurosci. 1998;18(9):3241-50.

33. Vande Velde C, Miller TM, Cashman NR, Cleveland DW. Selective association of misfolded ALSlinked mutant SOD1 with the cytoplasmic face of mitochondria. Proc Natl Acad Sci U S A. 2008;105(10):4022-7. doi:10.1073/pnas.0712209105.

34. Wang W, Wang L, Lu J, Siedlak SL, Fujioka H, Liang J et al. The inhibition of TDP-43 mitochondrial localization blocks its neuronal toxicity. Nat Med. 2016. doi:10.1038/nm.4130.

35. Perry TL, Krieger C, Hansen S, Eisen A. Amyotrophic lateral sclerosis: amino acid levels in plasma and cerebrospinal fluid. Ann Neurol. 1990;28(1):12-7. doi:10.1002/ana.410280105.

36. Shaw PJ, Forrest V, Ince PG, Richardson JP, Wastell HJ. CSF and plasma amino acid levels in motor neuron disease: elevation of CSF glutamate in a subset of patients. Neurodegeneration. 1995;4(2):20916.

37. Okamoto K, Hirai S, Amari M, Watanabe M, Sakurai A. Bunina bodies in amyotrophic lateral sclerosis immunostained with rabbit anti-cystatin C serum. Neurosci Lett. 1993;162(1-2):125-8.

38. Schmidt ML, Carden MJ, Lee VM, Trojanowski JQ. Phosphate dependent and independent neurofilament epitopes in the axonal swellings of patients with motor neuron disease and controls. Lab Invest. 1987;56(3):282-94.

39. Zhang B, Tu P, Abtahian F, Trojanowski JQ, Lee VM. Neurofilaments and orthograde transport are reduced in ventral root axons of transgenic mice that express human SOD1 with a G93A mutation. J Cell Biol. 1997;139(5):1307-15. 
40. Mackenzie IR, Bigio EH, Ince PG, Geser F, Neumann M, Cairns NJ et al. Pathological TDP-43 distinguishes sporadic amyotrophic lateral sclerosis from amyotrophic lateral sclerosis with SOD1 mutations. Ann Neurol. 2007;61(5):427-34. doi:10.1002/ana.21147.

41. Neumann M, Sampathu DM, Kwong LK, Truax AC, Micsenyi MC, Chou TT et al. Ubiquitinated TDP43 in frontotemporal lobar degeneration and amyotrophic lateral sclerosis. Science. 2006;314(5796):130-3. doi:10.1126/science.1134108.

42. Brettschneider J, Arai K, Del Tredici K, Toledo JB, Robinson JL, Lee EB et al. TDP-43 pathology and neuronal loss in amyotrophic lateral sclerosis spinal cord. Acta Neuropathol. 2014;128(3):423-37. doi:10.1007/s00401-014-1299-6.

43. Ludolph AC, Brettschneider J. TDP-43 in amyotrophic lateral sclerosis - is it a prion disease? Eur J Neurol. 2015;22(5):753-61. doi:10.1111/ene.12706.

44. Philips $T$, Robberecht $W$. Neuroinflammation in amyotrophic lateral sclerosis: role of glial activation in motor neuron disease. Lancet Neurol. 2011;10(3):253-63. doi:10.1016/S1474-4422(11)70015-1.

45. Brettschneider J, Toledo JB, Van Deerlin VM, Elman L, McCluskey L, Lee VM et al. Microglial activation correlates with disease progression and upper motor neuron clinical symptoms in amyotrophic lateral sclerosis. PLoS One. 2012;7(6):e39216. doi:10.1371/journal.pone.0039216.

46. Brooks BR, Miller RG, Swash M, Munsat TL, World Federation of Neurology Research Group on Motor Neuron D. El Escorial revisited: revised criteria for the diagnosis of amyotrophic lateral sclerosis. Amyotroph Lateral Scler Other Motor Neuron Disord. 2000;1(5):293-9.

47. Schrooten M, Smetcoren C, Robberecht W, Van Damme P. Benefit of the Awaji diagnostic algorithm for amyotrophic lateral sclerosis: a prospective study. Ann Neurol. 2011;70(1):79-83. doi:10.1002/ana.22380.

48. Galvin M, Madden C, Maguire S, Heverin M, Vajda A, Staines A et al. Patient journey to a specialist amyotrophic lateral sclerosis multidisciplinary clinic: an exploratory study. BMC Health Serv Res. 2015;15:571. doi:10.1186/s12913-015-1229-x.

49. Chio A, Pagani M, Agosta F, Calvo A, Cistaro A, Filippi M. Neuroimaging in amyotrophic lateral sclerosis: insights into structural and functional changes. Lancet Neurol. 2014;13(12):1228-40. doi:10.1016/S1474-4422(14)70167-X.

50. Peretti-Viton P, Azulay JP, Trefouret S, Brunel H, Daniel C, Viton JM et al. MRI of the intracranial corticospinal tracts in amyotrophic and primary lateral sclerosis. Neuroradiology. 1999;41(10):744-9.

51. Waragai M. MRI and clinical features in amyotrophic lateral sclerosis. Neuroradiology. 1997;39(12):847-51.

52. Cardenas-Blanco A, Machts J, Acosta-Cabronero J, Kaufmann J, Abdulla S, Kollewe K et al. Structural and diffusion imaging versus clinical assessment to monitor amyotrophic lateral sclerosis. Neuroimage Clin. 2016;11:408-14. doi:10.1016/j.nicl.2016.03.011.

53. Ciccarelli O, Behrens TE, Altmann DR, Orrell RW, Howard RS, Johansen-Berg $\mathrm{H}$ et al. Probabilistic diffusion tractography: a potential tool to assess the rate of disease progression in amyotrophic lateral sclerosis. Brain. 2006;129(Pt 7):1859-71. doi:10.1093/brain/awl100.

54. Wong JC, Concha L, Beaulieu C, Johnston W, Allen PS, Kalra S. Spatial profiling of the corticospinal tract in amyotrophic lateral sclerosis using diffusion tensor imaging. J Neuroimaging. 2007;17(3):23440. doi:10.1111/j.1552-6569.2007.00100.x.

55. Sheng L, Ma H, Zhong J, Shang H, Shi H, Pan P. Motor and extra-motor gray matter atrophy in amyotrophic lateral sclerosis: quantitative meta-analyses of voxel-based morphometry studies. Neurobiol Aging. 2015;36(12):3288-99. doi:10.1016/j.neurobiolaging.2015.08.018.

56. Agosta F, Canu E, Valsasina P, Riva N, Prelle A, Comi G et al. Divergent brain network connectivity in amyotrophic lateral sclerosis. Neurobiol Aging. 2013;34(2):419-27. doi:10.1016/j.neurobiolaging.2012.04.015.

57. Jelsone-Swain LM, Fling BW, Seidler RD, Hovatter R, Gruis K, Welsh RC. Reduced Interhemispheric Functional Connectivity in the Motor Cortex during Rest in Limb-Onset Amyotrophic Lateral Sclerosis. Front Syst Neurosci. 2010;4:158. doi:10.3389/fnsys.2010.00158. 
58. Zhou F, Xu R, Dowd E, Zang Y, Gong H, Wang Z. Alterations in regional functional coherence within the sensory-motor network in amyotrophic lateral sclerosis. Neurosci Lett. 2014;558:192-6. doi:10.1016/j.neulet.2013.11.022.

59. Filippini N, Douaud G, Mackay CE, Knight S, Talbot K, Turner MR. Corpus callosum involvement is a consistent feature of amyotrophic lateral sclerosis. Neurology. 2010;75(18):1645-52. doi:10.1212/WNL.0b013e3181fb84d1.

60. Quartuccio N, Van Weehaeghe D, Cistaro A, Jonsson C, Van Laere K, Pagani M. Positron emission tomography neuroimaging in amyotrophic lateral sclerosis: what is new? Q J Nucl Med Mol Imaging. 2014;58(4):344-54.

61. Dalakas MC, Hatazawa J, Brooks RA, Di Chiro G. Lowered cerebral glucose utilization in amyotrophic lateral sclerosis. Ann Neurol. 1987;22(5):580-6. doi:10.1002/ana.410220504.

62. Ludolph AC, Langen KJ, Regard M, Herzog H, Kemper B, Kuwert T et al. Frontal lobe function in amyotrophic lateral sclerosis: a neuropsychologic and positron emission tomography study. Acta Neurol Scand. 1992;85(2):81-9.

63. Hoffman JM, Mazziotta JC, Hawk TC, Sumida R. Cerebral glucose utilization in motor neuron disease. Arch Neurol. 1992;49(8):849-54.

64. Renard D, Collombier L, Castelnovo G, Fourcade G, Kotzki PO, LaBauge P. Brain FDG-PET changes in ALS and ALS-FTD. Acta Neurol Belg. 2011;111(4):306-9.

65. Cistaro A, Valentini MC, Chio A, Nobili F, Calvo A, Moglia C et al. Brain hypermetabolism in amyotrophic lateral sclerosis: a FDG PET study in ALS of spinal and bulbar onset. Eur J Nucl Med Mol Imaging. 2012;39(2):251-9. doi:10.1007/s00259-011-1979-6.

66. Pagani M, Chio A, Valentini MC, Oberg J, Nobili F, Calvo A et al. Functional pattern of brain FDGPET in amyotrophic lateral sclerosis. Neurology. 2014;83(12):1067-74. doi:10.1212/WNL.0000000000000792.

67. Van Laere K, Vanhee A, Verschueren J, De Coster L, Driesen A, Dupont P et al. Value of 18fluorodeoxyglucose-positron-emission tomography in amyotrophic lateral sclerosis: a prospective study. JAMA Neurol. 2014;71(5):553-61. doi:10.1001/jamaneurol.2014.62.

68. Van Weehaeghe D, Ceccarini J, Delva A, Robberecht W, Van Damme P, Van Laere K. Prospective Validation of 18F-FDG Brain PET Discriminant Analysis Methods in the Diagnosis of Amyotrophic Lateral Sclerosis. J Nucl Med. 2016. doi:10.2967/jnumed.115.166272.

69. Pagani M, Oberg J, De Carli F, Calvo A, Moglia C, Canosa A et al. Metabolic spatial connectivity in amyotrophic lateral sclerosis as revealed by independent component analysis. Hum Brain Mapp. 2016;37(3):942-53. doi:10.1002/hbm.23078.

70. Braak H, Brettschneider J, Ludolph AC, Lee VM, Trojanowski JQ, Del Tredici K. Amyotrophic lateral sclerosis--a model of corticofugal axonal spread. Nat Rev Neurol. 2013;9(12):708-14. doi:10.1038/nrneurol.2013.221.

71. Cistaro A, Pagani M, Montuschi A, Calvo A, Moglia C, Canosa A et al. The metabolic signature of C9ORF72-related ALS: FDG PET comparison with nonmutated patients. Eur J Nucl Med Mol Imaging. 2014;41(5):844-52. doi:10.1007/s00259-013-2667-5.

72. Elamin M, Phukan J, Bede P, Jordan N, Byrne S, Pender N et al. Executive dysfunction is a negative prognostic indicator in patients with ALS without dementia. Neurology. 2011;76(14):1263-9. doi:10.1212/WNL.0b013e318214359f.

73. Goldstein LH, Abrahams S. Changes in cognition and behaviour in amyotrophic lateral sclerosis: nature of impairment and implications for assessment. Lancet Neurol. 2013;12(4):368-80. doi:10.1016/S1474-4422(13)70026-7.

74. Pellerin L, Magistretti PJ. Glutamate uptake into astrocytes stimulates aerobic glycolysis: a mechanism coupling neuronal activity to glucose utilization. Proc Natl Acad Sci U S A. 1994;91(22):10625-9.

75. Abe K, Yorifuji S, Nishikawa Y. Reduced isotope uptake restricted to the motor area in patients with amyotrophic lateral sclerosis. Neuroradiology. 1993;35(6):410-1. 
76. Kew JJ, Leigh PN, Playford ED, Passingham RE, Goldstein LH, Frackowiak RS et al. Cortical function in amyotrophic lateral sclerosis. A positron emission tomography study. Brain. 1993;116 ( Pt 3):65580.

77. Waldemar G, Vorstrup S, Jensen TS, Johnsen A, Boysen G. Focal reductions of cerebral blood flow in amyotrophic lateral sclerosis: a [99mTc]-d,I-HMPAO SPECT study. J Neurol Sci. 1992;107(1):19-28.

78. Habert MO, Lacomblez L, Maksud P, El Fakhri G, Pradat JF, Meininger V. Brain perfusion imaging in amyotrophic lateral sclerosis: extent of cortical changes according to the severity and topography of motor impairment. Amyotroph Lateral Scler. 2007;8(1):9-15. doi:10.1080/14660820601048815.

79. Borasio GD, Linke R, Schwarz J, Schlamp V, Abel A, Mozley PD et al. Dopaminergic deficit in amyotrophic lateral sclerosis assessed with [I-123] IPT single photon emission computed tomography. J Neurol Neurosurg Psychiatry. 1998;65(2):263-5.

80. Przedborski S, Dhawan V, Donaldson DM, Murphy PL, McKenna-Yasek D, Mandel FS et al. Nigrostriatal dopaminergic function in familial amyotrophic lateral sclerosis patients with and without copper/zinc superoxide dismutase mutations. Neurology. 1996;47(6):1546-51.

81. Takahashi H, Snow BJ, Bhatt MH, Peppard R, Eisen A, Calne DB. Evidence for a dopaminergic deficit in sporadic amyotrophic lateral sclerosis on positron emission scanning. Lancet. 1993;342(8878):10168.

82. Lloyd CM, Richardson MP, Brooks DJ, Al-Chalabi A, Leigh PN. Extramotor involvement in ALS: PET studies with the GABA(A) ligand [(11)C]flumazenil. Brain. 2000;123 ( Pt 11):2289-96.

83. Turner MR, Hammers A, Al-Chalabi A, Shaw CE, Andersen PM, Brooks DJ et al. Distinct cerebral lesions in sporadic and 'D90A' SOD1 ALS: studies with [11C]flumazenil PET. Brain. 2005;128(Pt 6):13239. doi:10.1093/brain/awh509.

84. Wicks P, Turner MR, Abrahams S, Hammers A, Brooks DJ, Leigh PN et al. Neuronal loss associated with cognitive performance in amyotrophic lateral sclerosis: an (11C)-flumazenil PET study. Amyotroph Lateral Scler. 2008;9(1):43-9. doi:10.1080/17482960701737716.

85. Turner MR, Hammers A, Al-Chalabi A, Shaw CE, Andersen PM, Brooks DJ et al. Cortical involvement in four cases of primary lateral sclerosis using [(11)C]-flumazenil PET. J Neurol. 2007;254(8):1033-6. doi:10.1007/s00415-006-0482-7.

86. Turner MR, Rabiner EA, Hammers A, Al-Chalabi A, Grasby PM, Shaw CE et al. [11C]-WAY100635 PET demonstrates marked 5-HT1A receptor changes in sporadic ALS. Brain. 2005;128(Pt 4):896-905. doi:10.1093/brain/awh428.

87. Khandelwal PJ, Herman AM, Moussa CE. Inflammation in the early stages of neurodegenerative pathology. J Neuroimmunol. 2011;238(1-2):1-11. doi:10.1016/j.jneuroim.2011.07.002.

88. Hooten KG, Beers DR, Zhao W, Appel SH. Protective and Toxic Neuroinflammation in Amyotrophic Lateral Sclerosis. Neurotherapeutics. 2015;12(2):364-75. doi:10.1007/s13311-014-0329-3.

89. Alexianu ME, Kozovska M, Appel SH. Immune reactivity in a mouse model of familial ALS correlates with disease progression. Neurology. 2001;57(7):1282-9.

90. Hall ED, Oostveen JA, Gurney ME. Relationship of microglial and astrocytic activation to disease onset and progression in a transgenic model of familial ALS. Glia. 1998;23(3):249-56.

91. McEnery MW, Snowman AM, Trifiletti RR, Snyder SH. Isolation of the mitochondrial benzodiazepine receptor: association with the voltage-dependent anion channel and the adenine nucleotide carrier. Proc Natl Acad Sci U S A. 1992;89(8):3170-4.

92. Papadopoulos V, Amri H, Boujrad N, Cascio C, Culty M, Garnier M et al. Peripheral benzodiazepine receptor in cholesterol transport and steroidogenesis. Steroids. 1997;62(1):21-8.

93. Galiegue S, Tinel N, Casellas P. The peripheral benzodiazepine receptor: a promising therapeutic drug target. Curr Med Chem. 2003;10(16):1563-72.

94. Lavisse S, Garcia-Lorenzo D, Peyronneau MA, Bodini B, Thiriez C, Kuhnast B et al. Optimized Quantification of Translocator Protein Radioligand (1)(8)F-DPA-714 Uptake in the Brain of Genotyped Healthy Volunteers. J Nucl Med. 2015;56(7):1048-54. doi:10.2967/jnumed.115.156083.

95. Owen DR, Howell OW, Tang SP, Wells LA, Bennacef I, Bergstrom M et al. Two binding sites for [3H]PBR28 in human brain: implications for TSPO PET imaging of neuroinflammation. J Cereb Blood Flow Metab. 2010;30(9):1608-18. doi:10.1038/jcbfm.2010.63. 
96. Cagnin A, Gerhard A, Banati RB. In vivo imaging of neuroinflammation. Eur Neuropsychopharmacol. 2002;12(6):581-6.

97. Benavides J, Fage D, Carter C, Scatton B. Peripheral type benzodiazepine binding sites are a sensitive indirect index of neuronal damage. Brain Res. 1987;421(1-2):167-72.

98. Benavides J, Quarteronet D, Imbault F, Malgouris C, Uzan A, Renault C et al. Labelling of "peripheraltype" benzodiazepine binding sites in the rat brain by using [3H]PK 11195, an isoquinoline carboxamide derivative: kinetic studies and autoradiographic localization. J Neurochem. 1983;41(6):1744-50.

99. Le Fur G, Guilloux F, Rufat P, Benavides J, Uzan A, Renault $C$ et al. Peripheral benzodiazepine binding sites: effect of PK 11195, 1-(2-chlorophenyl)-N-methyl-(1-methylpropyl)-3 isoquinolinecarboxamide. II. In vivo studies. Life Sci. 1983;32(16):1849-56.

100. Le Fur G, Perrier ML, Vaucher N, Imbault F, Flamier A, Benavides J et al. Peripheral benzodiazepine binding sites: effect of PK 11195, 1-(2-chlorophenyl)-N-methyl-N-(1-methylpropyl)-3isoquinolinecarboxamide. I. In vitro studies. Life Sci. 1983;32(16):1839-47.

101. Rojas S, Martin A, Arranz MJ, Pareto D, Purroy J, Verdaguer E et al. Imaging brain inflammation with [(11)C]PK11195 by PET and induction of the peripheral-type benzodiazepine receptor after transient focal ischemia in rats. J Cereb Blood Flow Metab. 2007;27(12):1975-86. doi:10.1038/sj.jcbfm.9600500.

102. Gerhard A, Schwarz J, Myers R, Wise R, Banati RB. Evolution of microglial activation in patients after ischemic stroke: a [11C](R)-PK11195 PET study. Neuroimage. 2005;24(2):591-5. doi:10.1016/j.neuroimage.2004.09.034.

103. Cagnin A, Brooks DJ, Kennedy AM, Gunn RN, Myers R, Turkheimer FE et al. In-vivo measurement of activated microglia in dementia. Lancet. 2001;358(9280):461-7. doi:10.1016/S0140-6736(01)056252.

104. Banati RB, Newcombe J, Gunn RN, Cagnin A, Turkheimer F, Heppner F et al. The peripheral benzodiazepine binding site in the brain in multiple sclerosis: quantitative in vivo imaging of microglia as a measure of disease activity. Brain. 2000;123 ( Pt 11):2321-37.

105. Sitte HH, Wanschitz J, Budka H, Berger ML. Autoradiography with [3H]PK11195 of spinal tract degeneration in amyotrophic lateral sclerosis. Acta Neuropathol. 2001;101(2):75-8.

106. Engelhardt JI, Tajti J, Appel SH. Lymphocytic infiltrates in the spinal cord in amyotrophic lateral sclerosis. Arch Neurol. 1993;50(1):30-6.

107. Troost D, Van den Oord JJ, Vianney de Jong JM. Immunohistochemical characterization of the inflammatory infiltrate in amyotrophic lateral sclerosis. Neuropathol Appl Neurobiol. 1990;16(5):40110.

108. Turner MR, Cagnin A, Turkheimer FE, Miller CC, Shaw CE, Brooks DJ et al. Evidence of widespread cerebral microglial activation in amyotrophic lateral sclerosis: an [11C](R)-PK11195 positron emission tomography study. Neurobiol Dis. 2004;15(3):601-9. doi:10.1016/j.nbd.2003.12.012.

109. Zurcher NR, Loggia ML, Lawson R, Chonde DB, Izquierdo-Garcia D, Yasek JE et al. Increased in vivo glial activation in patients with amyotrophic lateral sclerosis: assessed with [(11)C]-PBR28. Neuroimage Clin. 2015;7:409-14. doi:10.1016/j.nicl.2015.01.009.

110. Chauveau F, Van Camp N, Dolle F, Kuhnast B, Hinnen F, Damont A et al. Comparative evaluation of the translocator protein radioligands 11C-DPA-713, 18F-DPA-714, and 11C-PK11195 in a rat model of acute neuroinflammation. J Nucl Med. 2009;50(3):468-76. doi:10.2967/jnumed.108.058669.

111. James ML, Fulton RR, Vercoullie J, Henderson DJ, Garreau L, Chalon S et al. DPA-714, a new translocator protein-specific ligand: synthesis, radiofluorination, and pharmacologic characterization. J Nucl Med. 2008;49(5):814-22. doi:10.2967/jnumed.107.046151.

112. Ory D, Planas A, Dresselaers T, Gsell W, Postnov A, Celen S et al. PET imaging of TSPO in a rat model of local neuroinflammation induced by intracerebral injection of lipopolysaccharide. Nucl Med Biol. 2015;42(10):753-61. doi:10.1016/j.nucmedbio.2015.06.010.

113. Arlicot N, Vercouillie J, Ribeiro MJ, Tauber C, Venel Y, Baulieu JL et al. Initial evaluation in healthy humans of [18F]DPA-714, a potential PET biomarker for neuroinflammation. Nucl Med Biol. 2012;39(4):570-8. doi:10.1016/j.nucmedbio.2011.10.012. 
114. Corcia P, Tauber C, Vercoullie J, Arlicot N, Prunier C, Praline J et al. Molecular imaging of microglial activation in amyotrophic lateral sclerosis. PLoS One. 2012;7(12):e52941. doi:10.1371/journal.pone.0052941.

115. Sperlagh B, Vizi ES, Wirkner K, Illes P. P2X7 receptors in the nervous system. Prog Neurobiol. 2006;78(6):327-46. doi:10.1016/j.pneurobio.2006.03.007.

116. North RA. Molecular physiology of P2X receptors. Physiol Rev. 2002;82(4):1013-67. doi:10.1152/physrev.00015.2002.

117. Monif M, Reid CA, Powell KL, Smart ML, Williams DA. The P2X7 receptor drives microglial activation and proliferation: a trophic role for P2X7R pore. J Neurosci. 2009;29(12):3781-91. doi:10.1523/JNEUROSCI.5512-08.2009.

118. Yiangou Y, Facer P, Durrenberger P, Chessell IP, Naylor A, Bountra C et al. COX-2, CB2 and P2X7immunoreactivities are increased in activated microglial cells/macrophages of multiple sclerosis and amyotrophic lateral sclerosis spinal cord. BMC Neurol. 2006;6:12. doi:10.1186/1471-2377-6-12.

119. Apolloni S, Amadio S, Montilli C, Volonte C, D'Ambrosi N. Ablation of P2X7 receptor exacerbates gliosis and motoneuron death in the SOD1-G93A mouse model of amyotrophic lateral sclerosis. Hum Mol Genet. 2013;22(20):4102-16. doi:10.1093/hmg/ddt259.

120. Duan S, Anderson CM, Keung EC, Chen Y, Chen Y, Swanson RA. P2X7 receptor-mediated release of excitatory amino acids from astrocytes. J Neurosci. 2003;23(4):1320-8.

121. Duan S, Neary JT. P2X(7) receptors: properties and relevance to CNS function. Glia. 2006;54(7):738-46. doi:10.1002/glia.20397.

122. Guile SD, Alcaraz L, Birkinshaw TN, Bowers KC, Ebden MR, Furber M et al. Antagonists of the P2X(7) receptor. From lead identification to drug development. J Med Chem. 2009;52(10):3123-41. doi:10.1021/jm801528x.

123. Gunosewoyo H, Coster MJ, Bennett MR, Kassiou M. Purinergic P2X(7) receptor antagonists: Chemistry and fundamentals of biological screening. Bioorg Med Chem. 2009;17(14):4861-5. doi:10.1016/j.bmc.2009.05.083.

124. Gunosewoyo H, Coster MJ, Kassiou M. Molecular probes for P2X7 receptor studies. Curr Med Chem. 2007;14(14):1505-23.

125. Able SL, Fish RL, Bye H, Booth L, Logan YR, Nathaniel C et al. Receptor localization, native tissue binding and ex vivo occupancy for centrally penetrant P2X7 antagonists in the rat. Br J Pharmacol. 2011;162(2):405-14. doi:10.1111/j.1476-5381.2010.01025.x.

126. Lord $B$, Ameriks MK, Wang $Q$, Fourgeaud $L$, Vliegen $M$, Verluyten $W$ et al. A novel radioligand for the ATP-gated ion channel P2X7: [(3)H] JNJ-54232334. Eur J Pharmacol. 2015;765:551-9. doi:10.1016/j.ejphar.2015.09.026.

127. Michel AD, Chambers LJ, Clay WC, Condreay JP, Walter DS, Chessell IP. Direct labelling of the human P2X7 receptor and identification of positive and negative cooperativity of binding. $\mathrm{Br} \mathrm{J}$ Pharmacol. 2007;151(1):103-14. doi:10.1038/sj.bjp.0707196.

128. Romagnoli R, Baraldi PG, Pavani MG, Tabrizi MA, Moorman AR, Di Virgilio F et al. Synthesis, radiolabeling, and preliminary biological evaluation of [3H]-1-[(S)-N,O-bis-(isoquinolinesulfonyl)- $\mathrm{N}$ methyl-tyrosyl]-4-(o-tolyl)-piperazi ne, a potent antagonist radioligand for the P2X7 receptor. Bioorg Med Chem Lett. 2004;14(22):5709-12. doi:10.1016/j.bmcl.2004.07.095.

129. Michel AD, Clay WC, Ng SW, Roman S, Thompson K, Condreay JP et al. Identification of regions of the $\mathrm{P} 2 \mathrm{X}(7)$ receptor that contribute to human and rat species differences in antagonist effects. $\mathrm{Br} \mathrm{J}$ Pharmacol. 2008;155(5):738-51. doi:10.1038/bjp.2008.306.

130. Ory D, Celen S, Gijsbers R, Van Den Haute C, Postnov A, Koole M et al. Preclinical evaluation of a P2X7 receptor selective radiotracer: PET studies in a rat model with local overexpression of the human P2X7 receptor and in non-human primates. J Nucl Med. 2016. doi:10.2967/jnumed.115.169995.

131. Janssen B, Vugts DJ, Funke U, Spaans A, Schuit RC, Kooijman E et al. Synthesis and initial preclinical evaluation of the P2X7 receptor antagonist [(1)(1)C]A-740003 as a novel tracer of neuroinflammation. J Labelled Comp Radiopharm. 2014;57(8):509-16. doi:10.1002/jlcr.3206. 
132. Abberley L, Bebius A, Beswick PJ, Billinton A, Collis KL, Dean DK et al. Identification of 2-oxo-N(phenylmethyl)-4-imidazolidinecarboxamide antagonists of the P2X(7) receptor. Bioorg Med Chem Lett. 2010;20(22):6370-4. doi:10.1016/j.bmcl.2010.09.101.

133. Ali Z, Laurijssens B, Ostenfeld T, McHugh S, Stylianou A, Scott-Stevens P et al. Pharmacokinetic and pharmacodynamic profiling of a P2X7 receptor allosteric modulator GSK1482160 in healthy human subjects. Br J Clin Pharmacol. 2013;75(1):197-207. doi:10.1111/j.1365-2125.2012.04320.x.

134. Seibert K, Zhang Y, Leahy K, Hauser S, Masferrer J, Isakson P. Distribution of COX-1 and COX-2 in normal and inflamed tissues. Adv Exp Med Biol. 1997;400A:167-70.

135. Yasojima K, Tourtellotte WW, McGeer EG, McGeer PL. Marked increase in cyclooxygenase-2 in ALS spinal cord: implications for therapy. Neurology. 2001;57(6):952-6.

136. Almer G, Guegan C, Teismann P, Naini A, Rosoklija G, Hays AP et al. Increased expression of the pro-inflammatory enzyme cyclooxygenase-2 in amyotrophic lateral sclerosis. Ann Neurol. 2001;49(2):176-85.

137. Pompl PN, Ho L, Bianchi M, McManus T, Qin W, Pasinetti GM. A therapeutic role for cyclooxygenase-2 inhibitors in a transgenic mouse model of amyotrophic lateral sclerosis. FASEB J. 2003;17(6):725-7. doi:10.1096/fj.02-0876fje.

138. Kaur J, Tietz O, Bhardwaj A, Marshall A, Way J, Wuest M et al. Design, Synthesis, and Evaluation of an (18)F-Labeled Radiotracer Based on Celecoxib-NBD for Positron Emission Tomography (PET) Imaging of Cyclooxygenase-2 (COX-2). ChemMedChem. 2015;10(10):1635-40. doi:10.1002/cmdc.201500287.

139. Tietz $O$, Marshall $A$, Wuest $M$, Wang $M$, Wuest $F$. Radiotracers for molecular imaging of cyclooxygenase-2 (COX-2) enzyme. Curr Med Chem. 2013;20(35):4350-69.

140. Fowler JS, Wang GJ, Logan J, Xie S, Volkow ND, MacGregor RR et al. Selective reduction of radiotracer trapping by deuterium substitution: comparison of carbon-11-L-deprenyl and carbon-11deprenyl-D2 for MAO B mapping. J Nucl Med. 1995;36(7):1255-62.

141. Aquilonius SM, Jossan SS, Ekblom JG, Askmark H, Gillberg PG. Increased binding of 3H-L-deprenyl in spinal cords from patients with amyotrophic lateral sclerosis as demonstrated by autoradiography. J Neural Transm Gen Sect. 1992;89(1-2):111-22.

142. Farid K, Carter SF, Rodriguez-Vieitez E, Almkvist O, Andersen P, Wall A et al. Case Report of Complex Amyotrophic Lateral Sclerosis with Cognitive Impairment and Cortical Amyloid Deposition. J Alzheimers Dis. 2015;47(3):661-7. doi:10.3233/JAD-141965.

143. Johansson A, Engler H, Blomquist $G$, Scott B, Wall A, Aquilonius SM et al. Evidence for astrocytosis in ALS demonstrated by [11C](L)-deprenyl-D2 PET. J Neurol Sci. 2007;255(1-2):17-22. doi:10.1016/j.jns.2007.01.057.

144. Coffey RG, Yamamoto Y, Snella E, Pross S. Tetrahydrocannabinol inhibition of macrophage nitric oxide production. Biochem Pharmacol. 1996;52(5):743-51.

145. Evens N, Vandeputte C, Coolen C, Janssen P, Sciot R, Baekelandt V et al. Preclinical evaluation of [11C]NE40, a type 2 cannabinoid receptor PET tracer. Nucl Med Biol. 2012;39(3):389-99. doi:10.1016/j.nucmedbio.2011.09.005.

146. Ahmad R, Koole M, Evens N, Serdons K, Verbruggen A, Bormans G et al. Whole-body biodistribution and radiation dosimetry of the cannabinoid type 2 receptor ligand [11C]-NE40 in healthy subjects. Mol Imaging Biol. 2013;15(4):384-90. doi:10.1007/s11307-013-0626-y.

147. Mu L, Bieri D, Slavik R, Drandarov K, Muller A, Cermak S et al. Radiolabeling and in vitro /in vivo evaluation of $\mathrm{N}$-(1-adamantyl)-8-methoxy-4-oxo-1-phenyl-1,4-dihydroquinoline-3-carboxamide as a PET probe for imaging cannabinoid type 2 receptor. J Neurochem. 2013;126(5):616-24. doi:10.1111/jnc.12354.

148. Slavik R, Herde AM, Bieri D, Weber M, Schibli R, Kramer SD et al. Synthesis, radiolabeling and evaluation of novel 4-oxo-quinoline derivatives as PET tracers for imaging cannabinoid type 2 receptor. Eur J Med Chem. 2015;92:554-64. doi:10.1016/j.ejmech.2015.01.028.

149. Slavik R, Grether U, Muller Herde A, Gobbi L, Fingerle J, Ullmer C et al. Discovery of a high affinity and selective pyridine analog as a potential positron emission tomography imaging agent for cannabinoid type 2 receptor. J Med Chem. 2015;58(10):4266-77. doi:10.1021/acs.jmedchem.5b00283. 
150. Sperlagh B, Illes P. P2X7 receptor: an emerging target in central nervous system diseases. Trends Pharmacol Sci. 2014;35(10):537-47. doi:10.1016/j.tips.2014.08.002.

151. Aronica E, Catania MV, Geurts J, Yankaya B, Troost D. Immunohistochemical localization of group I and II metabotropic glutamate receptors in control and amyotrophic lateral sclerosis human spinal cord: upregulation in reactive astrocytes. Neuroscience. 2001;105(2):509-20.

152. Hamill TG, Krause S, Ryan C, Bonnefous C, Govek S, Seiders TJ et al. Synthesis, characterization, and first successful monkey imaging studies of metabotropic glutamate receptor subtype 5 (mGluR5) PET radiotracers. Synapse. 2005;56(4):205-16. doi:10.1002/syn.20147.

153. Brownell AL, Kuruppu D, Kil KE, Jokivarsi K, Poutiainen P, Zhu A et al. PET imaging studies show enhanced expression of mGluR5 and inflammatory response during progressive degeneration in ALS mouse model expressing SOD1-G93A gene. J Neuroinflammation. 2015;12(1):217. doi:10.1186/s12974-015-0439-9.

154. Giribaldi F, Milanese M, Bonifacino T, Anna Rossi PI, Di Prisco S, Pittaluga A et al. Group I metabotropic glutamate autoreceptors induce abnormal glutamate exocytosis in a mouse model of amyotrophic lateral sclerosis. Neuropharmacology. 2013;66:253-63. doi:10.1016/j.neuropharm.2012.05.018.

155. Milanese M, Giribaldi F, Melone M, Bonifacino T, Musante I, Carminati E et al. Knocking down metabotropic glutamate receptor 1 improves survival and disease progression in the SOD1(G93A) mouse model of amyotrophic lateral sclerosis. Neurobiol Dis. 2014;64:48-59. doi:10.1016/j.nbd.2013.11.006.

156. Zanotti-Fregonara P, Barth VN, Liow JS, Zoghbi SS, Clark DT, Rhoads E et al. Evaluation in vitro and in animals of a new 11C-labeled PET radioligand for metabotropic glutamate receptors 1 in brain. Eur J Nucl Med Mol Imaging. 2013;40(2):245-53. doi:10.1007/s00259-012-2269-7.

157. Zanotti-Fregonara P, Barth VN, Zoghbi SS, Liow JS, Nisenbaum E, Siuda E et al. 11C-LY2428703, a positron emission tomographic radioligand for the metabotropic glutamate receptor 1 , is unsuitable for imaging in monkey and human brains. EJNMMI Res. 2013;3(1):47. doi:10.1186/2191-219X-3-47.

158. Zanotti-Fregonara P, Xu R, Zoghbi SS, Liow JS, Fujita M, Veronese M et al. The PET Radioligand 18F-FIMX Images and Quantifies Metabotropic Glutamate Receptor 1 in Proportion to the Regional Density of Its Gene Transcript in Human Brain. J Nucl Med. 2016;57(2):242-7. doi:10.2967/jnumed.115.162461.

159. Crevecoeur J, Kaminski RM, Rogister B, Foerch P, Vandenplas C, Neveux M et al. Expression pattern of synaptic vesicle protein 2 (SV2) isoforms in patients with temporal lobe epilepsy and hippocampal sclerosis. Neuropathol Appl Neurobiol. 2014;40(2):191-204. doi:10.1111/nan.12054.

160. Glantz LA, Lewis DA. Decreased dendritic spine density on prefrontal cortical pyramidal neurons in schizophrenia. Arch Gen Psychiatry. 2000;57(1):65-73.

161. Kang HJ, Voleti B, Hajszan T, Rajkowska G, Stockmeier CA, Licznerski P et al. Decreased expression of synapse-related genes and loss of synapses in major depressive disorder. Nat Med. 2012;18(9):14137. doi:10.1038/nm.2886.

162. Robinson JL, Molina-Porcel L, Corrada MM, Raible K, Lee EB, Lee VM et al. Perforant path synaptic loss correlates with cognitive impairment and Alzheimer's disease in the oldest-old. Brain. 2014;137(Pt 9):2578-87. doi:10.1093/brain/awu190.

163. Sunico CR, Dominguez G, Garcia-Verdugo JM, Osta R, Montero F, Moreno-Lopez B. Reduction in the motoneuron inhibitory/excitatory synaptic ratio in an early-symptomatic mouse model of amyotrophic lateral sclerosis. Brain Pathol. 2011;21(1):1-15. doi:10.1111/j.1750-3639.2010.00417.x.

164. Gorrie GH, Fecto F, Radzicki D, Weiss C, Shi Y, Dong H et al. Dendritic spinopathy in transgenic mice expressing ALS/dementia-linked mutant UBQLN2. Proc Natl Acad Sci U S A. 2014;111(40):145249. doi:10.1073/pnas.1405741111.

165. Buckley K, Kelly RB. Identification of a transmembrane glycoprotein specific for secretory vesicles of neural and endocrine cells. J Cell Biol. 1985;100(4):1284-94.

166. Mendoza-Torreblanca JG, Vanoye-Carlo A, Phillips-Farfan BV, Carmona-Aparicio L, Gomez-Lira G. Synaptic vesicle protein 2A: basic facts and role in synaptic function. Eur J Neurosci. 2013;38(11):352939. doi:10.1111/ejn.12360. 
167. Estrada S, Lubberink $M$, Thibblin A, Sprycha $M$, Buchanan T, Mestdagh $N$ et al. [(11)C]UCB-A, a novel PET tracer for synaptic vesicle protein 2A. Nucl Med Biol. 2016;43(6):325-32. doi:10.1016/j.nucmedbio.2016.03.004.

168. Nabulsi NB, Mercier J, Holden D, Carre S, Najafzadeh S, Vandergeten MC et al. Synthesis and Preclinical Evaluation of 11C-UCB-J as a PET Tracer for Imaging the Synaptic Vesicle Glycoprotein 2A in the Brain. J Nucl Med. 2016;57(5):777-84. doi:10.2967/jnumed.115.168179.

169. Warnock GI, Aerts J, Bahri MA, Bretin F, Lemaire C, Giacomelli F et al. Evaluation of 18F-UCB-H as a novel PET tracer for synaptic vesicle protein 2A in the brain. J Nucl Med. 2014;55(8):1336-41. doi:10.2967/jnumed.113.136143.

170. Finnema SJ, Nabulsi NB, Eid T, Detyniecki K, Lin SF, Chen MK et al. Imaging synaptic density in the living human brain. Sci Transl Med. 2016;8(348):348ra96. doi:10.1126/scitransImed.aaf6667.

171. Bruijn LI, Houseweart MK, Kato S, Anderson KL, Anderson SD, Ohama E et al. Aggregation and motor neuron toxicity of an ALS-linked SOD1 mutant independent from wild-type SOD1. Science. 1998;281(5384):1851-4.

172. Julien JP. Neurofilaments and motor neuron disease. Trends Cell Biol. 1997;7(6):243-9. doi:10.1016/S0962-8924(97)01049-0.

173. Van Deerlin VM, Leverenz JB, Bekris LM, Bird TD, Yuan W, Elman LB et al. TARDBP mutations in amyotrophic lateral sclerosis with TDP-43 neuropathology: a genetic and histopathological analysis. Lancet Neurol. 2008;7(5):409-16. doi:10.1016/S1474-4422(08)70071-1.

174. Zetterstrom P, Stewart HG, Bergemalm D, Jonsson PA, Graffmo KS, Andersen PM et al. Soluble misfolded subfractions of mutant superoxide dismutase-1s are enriched in spinal cords throughout life in murine ALS models. Proc Natl Acad Sci U S A. 2007;104(35):14157-62. doi:10.1073/pnas.0700477104.

175. Hamilton RL, Bowser R. Alzheimer disease pathology in amyotrophic lateral sclerosis. Acta Neuropathol. 2004;107(6):515-22. doi:10.1007/s00401-004-0843-1.

176. Bryson JB, Hobbs C, Parsons MJ, Bosch KD, Pandraud A, Walsh FS et al. Amyloid precursor protein (APP) contributes to pathology in the SOD1(G93A) mouse model of amyotrophic lateral sclerosis. Hum Mol Genet. 2012;21(17):3871-82. doi:10.1093/hmg/dds215.

177. Yamakawa Y, Shimada H, Ataka S, Tamura A, Masaki H, Naka H et al. Two cases of dementias with motor neuron disease evaluated by Pittsburgh compound B-positron emission tomography. Neurol Sci. 2012;33(1):87-92. doi:10.1007/s10072-011-0479-6.

178. Matias-Guiu JA, Pytel V, Cabrera-Martin MN, Galan L, Valles-Salgado M, Guerrero A et al. Amyloidand FDG-PET imaging in amyotrophic lateral sclerosis. Eur J Nucl Med Mol Imaging. 2016. doi:10.1007/s00259-016-3434-1.

179. D'Amico E, Factor-Litvak P, Santella RM, Mitsumoto H. Clinical perspective on oxidative stress in sporadic amyotrophic lateral sclerosis. Free Radic Biol Med. 2013;65:509-27. doi:10.1016/j.freeradbiomed.2013.06.029.

180. Manfredi G, Xu Z. Mitochondrial dysfunction and its role in motor neuron degeneration in ALS. Mitochondrion. 2005;5(2):77-87. doi:10.1016/j.mito.2005.01.002.

181. Fujibayashi Y, Taniuchi H, Yonekura Y, Ohtani H, Konishi J, Yokoyama A. Copper-62-ATSM: a new hypoxia imaging agent with high membrane permeability and low redox potential. J Nucl Med. 1997;38(7):1155-60.

182. Vavere AL, Lewis JS. CU-ATSM: a radiopharmaceutical for the PET imaging of hypoxia. Dalton Trans. 2007(43):4893-902. doi:10.1039/b705989b.

183. Donnelly PS, Liddell JR, Lim S, Paterson BM, Cater MA, Savva MS et al. An impaired mitochondrial electron transport chain increases retention of the hypoxia imaging agent diacetylbis(4methylthiosemicarbazonato)copperll. Proc Natl Acad Sci U S A. 2012;109(1):47-52. doi:10.1073/pnas.1116227108.

184. Yoshii Y, Yoneda M, Ikawa M, Furukawa T, Kiyono Y, Mori T et al. Radiolabeled Cu-ATSM as a novel indicator of overreduced intracellular state due to mitochondrial dysfunction: studies with mitochondrial DNA-less rho0 cells and cybrids carrying MELAS mitochondrial DNA mutation. Nucl Med Biol. 2012;39(2):177-85. doi:10.1016/j.nucmedbio.2011.08.008. 
185. Ikawa M, Okazawa H, Arakawa K, Kudo T, Kimura H, Fujibayashi Y et al. PET imaging of redox and energy states in stroke-like episodes of MELAS. Mitochondrion. 2009;9(2):144-8. doi:10.1016/j.mito.2009.01.011.

186. Ikawa $M$, Okazawa $H$, Kudo $T$, Kuriyama $M$, Fujibayashi $Y$, Yoneda $M$. Evaluation of striatal oxidative stress in patients with Parkinson's disease using [62Cu]ATSM PET. Nucl Med Biol. 2011;38(7):945-51. doi:10.1016/j.nucmedbio.2011.02.016.

187. Ikawa M, Okazawa H, Tsujikawa T, Matsunaga A, Yamamura O, Mori T et al. Increased oxidative stress is related to disease severity in the ALS motor cortex: A PET study. Neurology. 2015;84(20):20339. doi:10.1212/WNL.0000000000001588.

188. McAllum EJ, Lim NK, Hickey JL, Paterson BM, Donnelly PS, Li QX et al. Therapeutic effects of Cull(atsm) in the SOD1-G37R mouse model of amyotrophic lateral sclerosis. Amyotroph Lateral Scler Frontotemporal Degener. 2013;14(7-8):586-90. doi:10.3109/21678421.2013.824000.

189. Soon CP, Donnelly PS, Turner BJ, Hung LW, Crouch PJ, Sherratt NA et al. Diacetylbis(N(4)methylthiosemicarbazonato) copper(II) (Cull(atsm)) protects against peroxynitrite-induced nitrosative damage and prolongs survival in amyotrophic lateral sclerosis mouse model. J Biol Chem. 2011;286(51):44035-44. doi:10.1074/jbc.M111.274407.

190. Williams JR, Trias E, Beilby PR, Lopez NI, Labut EM, Bradford CS et al. Copper delivery to the CNS by CUATSM effectively treats motor neuron disease in SOD(G93A) mice co-expressing the CopperChaperone-for-SOD. Neurobiol Dis. 2016;89:1-9. doi:10.1016/j.nbd.2016.01.020. 
Table 1: Overview of tracer molecules applied for ALS imaging

\begin{tabular}{|c|c|c|c|}
\hline Pathological hallmark & Target & Tracer & References \\
\hline Glucose metabolism & $\begin{array}{c}\text { GLUT (predominant GLUT } \\
\text { 1) }\end{array}$ & {$\left[{ }^{18} \mathrm{~F}\right]-\mathrm{FDG}$} & $61-69,74$ \\
\hline Cerebral blood flow & & $\begin{array}{c}{\left[{ }^{15} \mathrm{O}\right]-\mathrm{H}_{2} \mathrm{O}} \\
{\left[{ }^{99 \mathrm{~m}} \mathrm{Tc}\right]-\mathrm{d}, 1-\mathrm{HMPO}} \\
{\left[{ }^{99 \mathrm{~m}} \mathrm{Tc}\right]-\mathrm{ECD}}\end{array}$ & $75-78$ \\
\hline $\begin{array}{c}\text { Dopaminergic nigrostriatal } \\
\text { tract }\end{array}$ & Dopaminergic cells & $\begin{array}{c}{\left[{ }^{18} \mathrm{~F}\right]-\mathrm{DOPA}} \\
{\left[{ }^{123} \mathrm{I}\right]-\mathrm{IPT}}\end{array}$ & $\begin{array}{c}79 \\
80-81\end{array}$ \\
\hline Serotonergic system & 5-HT1A Receptor & {$\left[{ }^{11} \mathrm{C}\right]-$ WAY100635 } & 86 \\
\hline \multirow[t]{15}{*}{ Neuro-inflammation } & TSPO & $\begin{array}{c}{\left[{ }^{11} \mathrm{C}\right]-(\mathrm{R})-\mathrm{PK} 11195} \\
{\left[{ }^{11} \mathrm{C}\right]-\mathrm{PBR} 28} \\
{\left[{ }^{18} \mathrm{~F}\right]-\mathrm{DPA}-714}\end{array}$ & $\begin{array}{l}94-108 \\
109,150 \\
110-114\end{array}$ \\
\hline & \multirow[t]{7}{*}{ P2X7 Receptor } & {$\left[{ }^{3} \mathrm{H}\right]-\mathrm{A}-804598$} & 125 \\
\hline & & {$[(3) \mathrm{H}]-J N J-54232334$} & 126 \\
\hline & & Compound-17 & 127 \\
\hline & & Compound-13 & 128 \\
\hline & & {$\left[{ }^{11} \mathrm{C}\right]-J N J-54173717$} & 129 \\
\hline & & {$\left[{ }^{11} \mathrm{C}\right]-\mathrm{A}-740003$} & 131 \\
\hline & & {$\left[{ }^{11} \mathrm{C}\right]-\mathrm{GSK} 1482160$} & $132-133$ \\
\hline & \multirow[t]{2}{*}{$\operatorname{cox}-2$} & {$\left[{ }^{11} \mathrm{C}\right]$-celecoxib } & 138 \\
\hline & & $\begin{array}{c}{\left[{ }^{11} \mathrm{C}\right] /\left[{ }^{18} \mathrm{~F}\right] \text {-celecoxib }} \\
\text { derivatives }\end{array}$ & 139 \\
\hline & MAO-B & {$\left[{ }^{11} \mathrm{C}\right]$-deprenyl-D2 } & $140-143$ \\
\hline & \multirow[t]{4}{*}{$\mathrm{CB} 2 \mathrm{R}$} & {$\left[{ }^{11} \mathrm{C}\right]-\mathrm{NE} 40$} & 145,146 \\
\hline & & {$\left[{ }^{11} \mathrm{C}\right]-\mathrm{KD} 2$} & 147 \\
\hline & & {$\left[{ }^{11} \mathrm{C}\right]-\mathrm{RS}-016$} & 148 \\
\hline & & {$\left[{ }^{11} \mathrm{C}\right]-\mathrm{RSR}-056$} & 149 \\
\hline \multirow[t]{2}{*}{ Excitotoxity } & mGluR5 & {$\left[{ }^{18} \mathrm{~F}\right]-\mathrm{FPEB}$ PET } & $150-153$ \\
\hline & mGluR1 & {$\left[{ }^{18} \mathrm{~F}\right]-\mathrm{FIMX}$} & 158 \\
\hline \multirow[t]{3}{*}{ Synaptic density } & SV2A & {$\left[{ }^{11} \mathrm{C}\right]-U C B-A$} & 167 \\
\hline & & {$\left[{ }^{18} \mathrm{~F}\right]-\mathrm{UCB}-\mathrm{H}$} & 169 \\
\hline & & {$\left[{ }^{11} \mathrm{C}\right]-U C B-J$} & $168-170$ \\
\hline Inhibitory dysfunction & GABA A-R & {$\left[{ }^{11} \mathrm{C}\right]$-Flumazenil } & $82-85$ \\
\hline Protein aggregation & Beta-amyloid & {$\left[{ }^{11} \mathrm{C}\right]-\mathrm{PIB}$} & 142,177 \\
\hline Mitochondrial dysfunction & Mitochondria & {$\left[{ }^{62} \mathrm{Cu}\right]-\mathrm{ATSM}$} & $181-190$ \\
\hline
\end{tabular}

